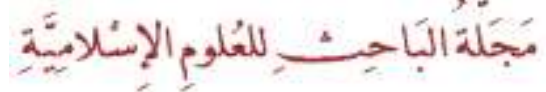

Researcher Journal For Islamic Sciences

Published by the College of Islamic Sciences at the University of Fallujah

ISSN p.p:2708-3993 / ISSN 0.l: 2708-4000

Vol;1- Issue;1/ (2020-2021)

\section{Courtship's Effect On Calling To Allah}

\section{Almighty}

\section{Osama Abdulmuni'm Shakir/ A Teacher At Um Al-Masajid Qura'n}

Reading High School In Fallujah/a.manhm85@gmail.com/ 07824916023

Abstract: This is a study in a sublime character, which every Muslim and preacher should behave with and be characterized by. Namely, the moral of courtship to people and its effect on the call to Allah, through which I showed the manners of courtship that the preacher should possess as our prophet was, peace and blessings be upon him. One of these manners is to smile in the faces of the invitees. Then I spoke about respect. There is no way to the hearts of the people without it. then I talked about visiting and the effect it has on the invitees. There are material means that lead to courtship, first of which is the gift, as it was said: "Gift cools hearts", and from the means is the gift of "Whose hearts have been reconciled to Truth", so I commend it then I concluded the research by means of holding banquets, and I mentioned evidence for every method from the purified Sunnah.

Keywords: (Effect, courtship, calling, moral, manners).

ro

Doi:10.37940/RJIS 2021.1.7 


\section{التودد وأثره في الدعوة إلى الله تعالى}

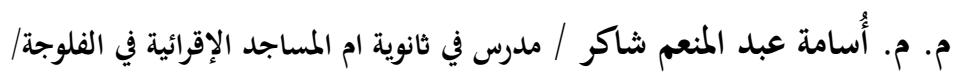

a.manhm85@gmail.com/07824916023

الملتخص:

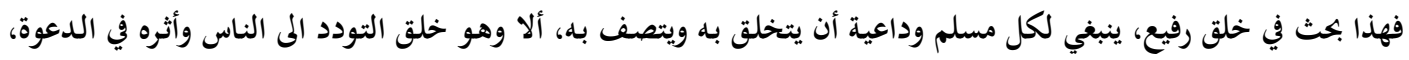

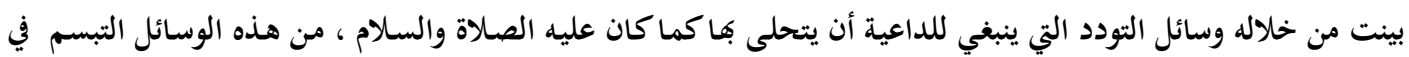

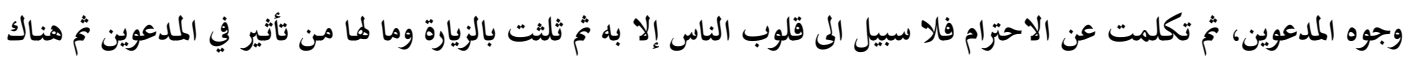

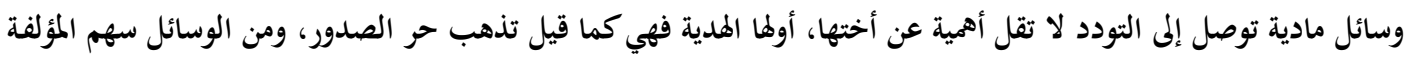

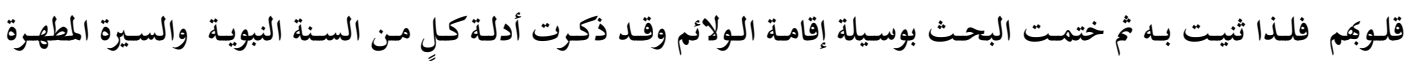
.الكلمات المفتاحية: (التودد، الأثر، الدعوة، الأخلاق، السلوك). 


\section{التودد وأثره في الدعوة إلى الله تعالى

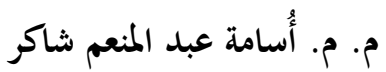

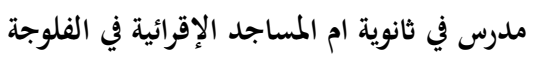

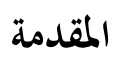

الحمد الله رب العالمين، وأفضل الصلاة وأتم التسليم على سيدنا يُمَّمَ وعلى آله وصحبه أجمعين.

وبعد: فإنّ ميدان البحث في حقل الدعوة إلى الله تعالى واسع في مجالاته، متنوع في فروعه، متعدد في

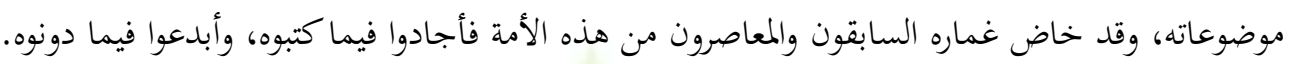

ولما أردت كتابة بحث في ميدان تخصصي الدعوي، تزامت عليّ الأفكار، ودار في خلدي كثير من

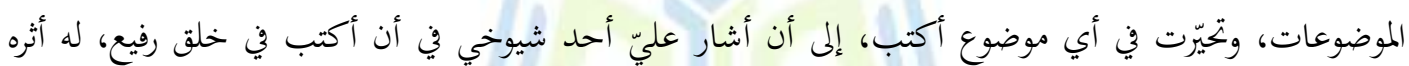

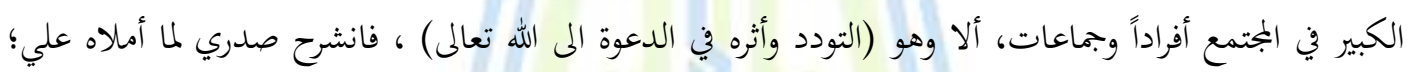

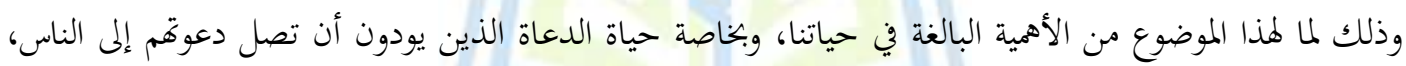

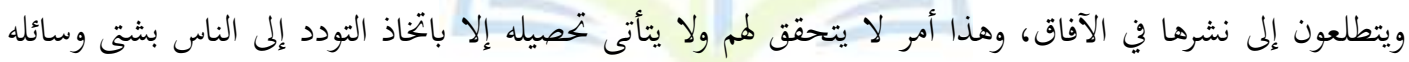
إذ هو سفينة توصلهم إلى مقصودهم، وتبحر بكم إلى غاية مطلوبكم.

\section{ومنهجي في هذا البحث كالآتي: ا ـ ـ عرفت وسائل التودد لغة واصطلاحا.}

r. ترجمت لبعض الأعلام غير المشهورين وتركت ترجمة غيرهم وذكرت سنة الوفاة لبعضهم. r. لم أذكر بطاقة الكتاب في الموامش واكتفيت بذكرها فقط في قائمة المصادر والمراجع. وقد اشتمل بكثي بعد هذه المقدمة على تههيد ومبحثين وخاتمة، وذلك على النحو الآتي: التمهيد وفيه أعرّف بالألفاظ الواردة في عنوان البحث: 


$$
\text { ثأثانيا: تعريف الأثر لغة واصطلاحاً. }
$$

المبحث الاول: التودد بالوسائل المعنوية، ويشتمل على ثلاثة مطالب:

$$
\text { المطلب الاول: التبسم وأثره في الدعوة إلى الله تعالى. }
$$$$
\text { المطلب الثاني: الاحترام وأثره في الدعوة إلى الله تعالى. }
$$$$
\text { المطلب الثالث: الزيارة وأثرها في الدعوة إلى الله تعالى. }
$$

المبحث الثاني: التودد بالوسائل المادية، ويشتمل على ثلاثة مطالب:

$$
\text { المطلب الاول: الهدية وأثرها في الدعوة إلى الله تعالى. }
$$

المطلب الثاني: سهم المؤلفة قلوبم وأثره في الدعوة إلى الله تعالى.

$$
\text { المطلب الثالث: اقامة الولائم وأثرها في الدعوة إلى الله تعالى. }
$$

وأما الخاتمة فسأضمّنها أهم النتائج التي توصلت إليها في هذا البحث.

وقد واجهتني بعض الصعوبات من حيث قلة المصادر الدعوية، لكنها ذللت بفضل الله وتوفيقه

هذا وما كان من خير وصواب فمن الله وحده، وله الفضل والمنة، وما كان غير ذلك من قصور أو خلل

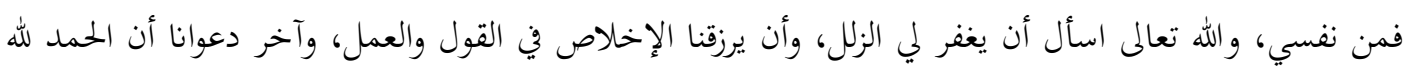

$$
\text { رب العالمين. }
$$

$$
\text { الباحث }
$$

rTh 


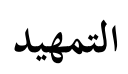

ويشتمل:

$$
\text { أولا: تعريف التودد لغة واصطلاحًا: }
$$

$$
\text { التودد في اللغة: مصدر ودَّدَ يتودَّد فهو مُتودِّد، والمفعول مُتودَّد، }
$$

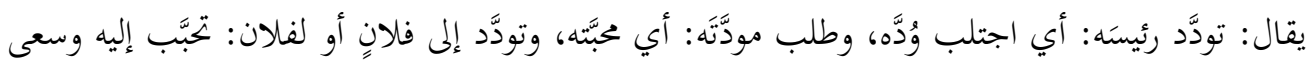

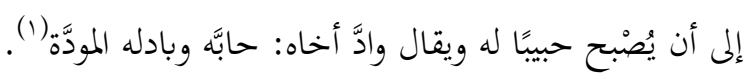
أما التودد في الاصطلاح: فقد اختلفت عبارات العلماء فيه وتباينت: إذ قد عرفه الشريف الجرجاني بأنه:

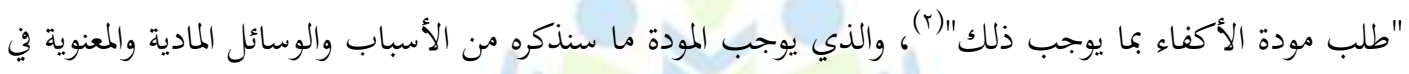

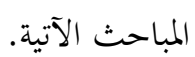

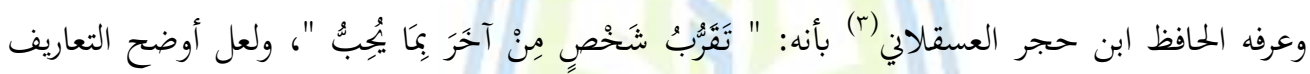

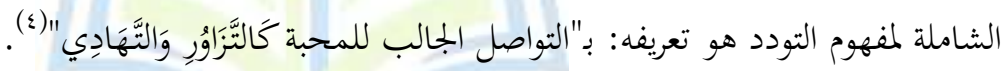
فالتودد إذن هو: كل فعل او قول يكون سببا للمحبة، وسببا لقبول كلام الداعي والتأثر به.

$$
\text { ثانيًا: تعريف الأثر لغة واصطلاحا: }
$$

الأََثر في اللغة: يطلق على ما بقي من رسم الشيء وضربة السيف، كما أنه يطلق على الاستبداد بالشيء

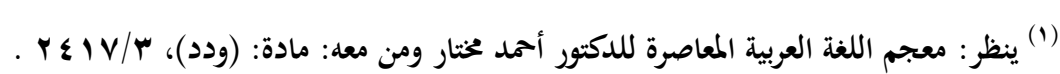

$$
\begin{aligned}
& \text { (r) }
\end{aligned}
$$

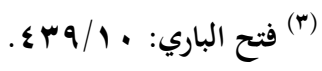

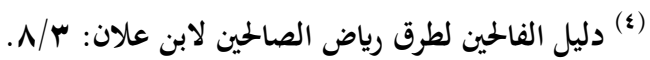




\section{يقال: استأثَرَ بالشيء استبد به، وأثَارَةٌ من علم أي بقية منه، أما التأثيرُ فهو إبقاء الأثر في الشيء (').}

الأثر في الاصطلاح: له" ثلاثة معالٍ: الأول، بمعنى: النتيجة، وهو الحاصل من الشيء، والثاني بمعنى

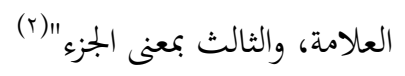

ثالثًا: الدعوة لغة واصطلاحا:

الدعوة في اللغة: لها معالٍ عديدة: فتطلق ويراد منها النداء: تقول "دعوت فلانا، ناديته"(r)، كما تطلق

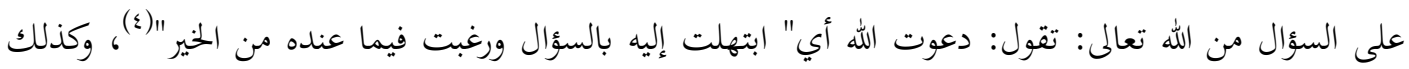
تطلق على التسمية: تقول "دعوت زيدا إذا سميته"(•) أما الدعوة في الاصطلاح: فقد تباينت آراء العلماء في تعريف الدعوة، وذلك تبعاً لاختلافهم في تحديد

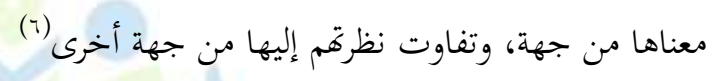

فبعضهم نظر إلى الدعوة على أها دعوة إلى الإسلام، وبيان لما جاء به كالإمام ابن تيمية رمهـ

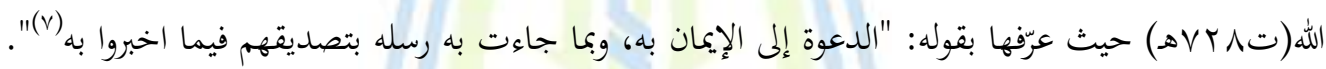

ومن العلماء من أدخل في تعريف الدعوة أهدافها وغايتها كما فعل الشيخ يُمَّمَ الغزالي رحمه الله (7 أ اهـ)

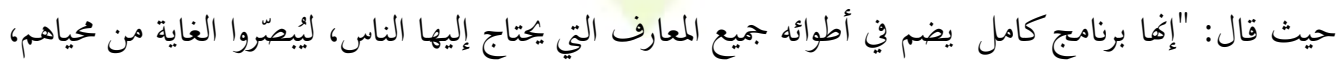

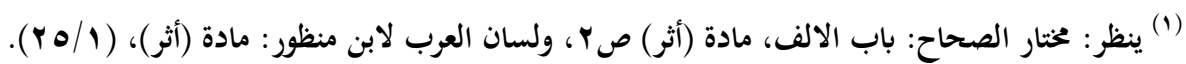

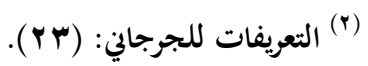

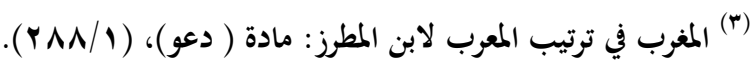

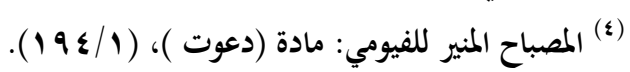

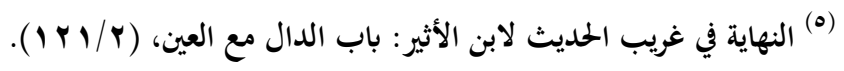

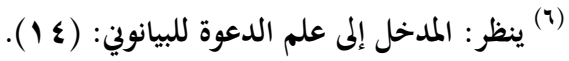

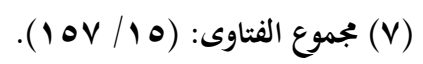

$r \leq$. 
ولعل من أفضل من عرف الدعوة تعريفاً جامعا مانعا يتماشى مع مسالك العلماء السابقين في تعريفاتم

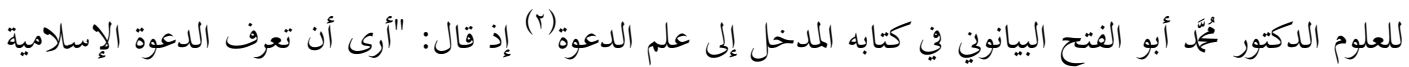
اصطلاحا بأنه: تبليغ الإسلام للناس وتعليمه إياهم، وتطبيقه في واقع الحياة ". فقد شمل تعريفه مراحل الدعوة الثلاث (التبليغية، والتكونية -التعليمية-، والتنفيذية) التي بيّها الله تعالى في

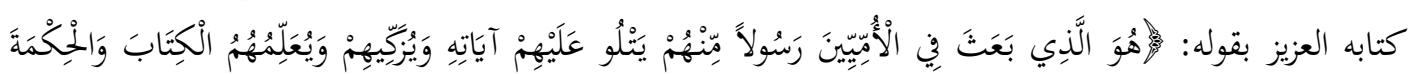

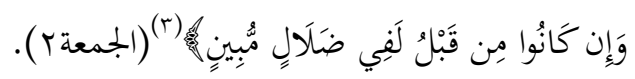

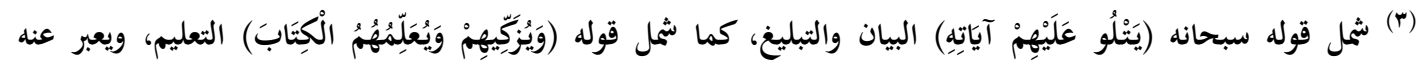

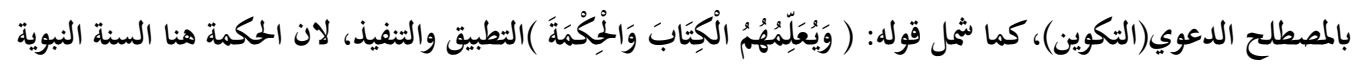

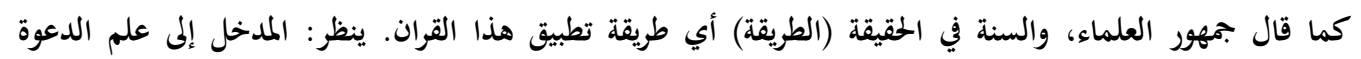
كلبيانوين: (lv). r 1 


\section{المطلب الأول: التبسم وأثره في الدعوة إلى الله}

التبسم لغة هو: دون الضحك وأحسنه يقال: بَسَمَ بالفتح يبسِمُ بَسْماً فهو باسمُ، وَرجل بَسَّام وامرأةٌ بَسّامة(1). أما اصطلاحا: فقد عرفه العلماء بأنه هو: الذي لا يكون مسموعا للشخص نفسه ولا لجيرانه (r)، فهو فعل

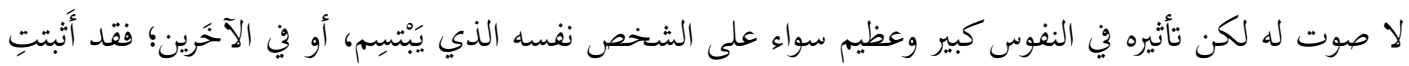

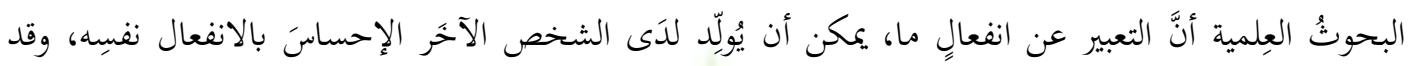

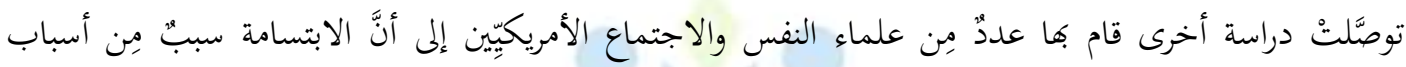

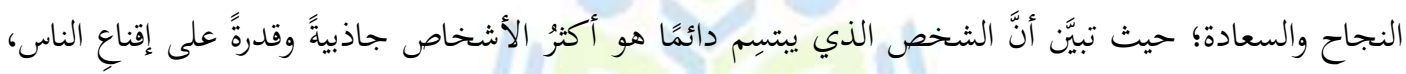

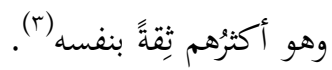
لذا قد كان قدوة الدعاة ومعلمهم من أكثر الناس تبسمًا في وجوه أصحابه.

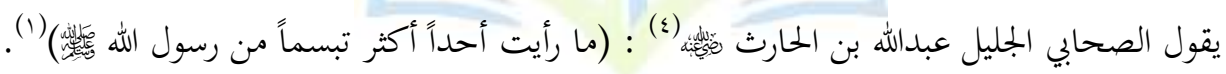

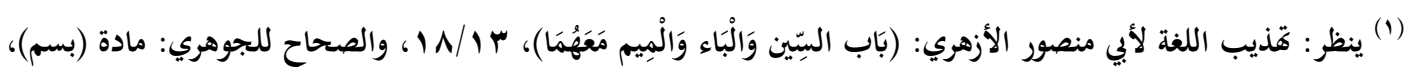

$$
\text { (r) }
$$

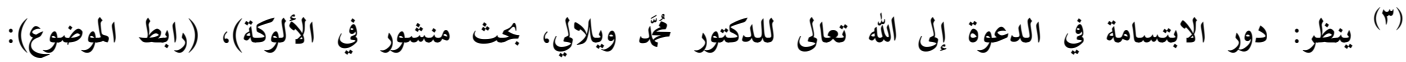
https://www.alukah.net/sharia/0/27913/\#ixzz6D1PopZlJ

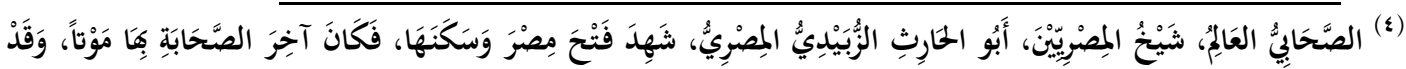

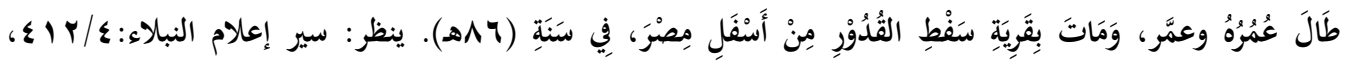

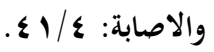
$r \leq r$ 
ولقد اهتم الإسلام بهذه الوسيلة اهتماما بالغا؛ حتى جعل الابتسامة دينا يتعبد به فقال

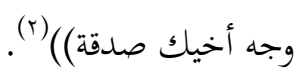

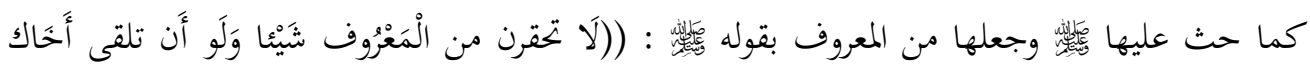

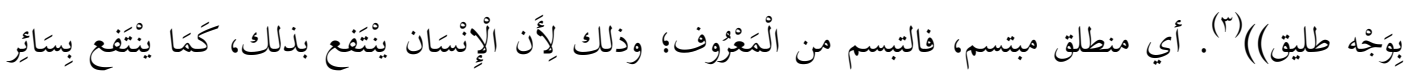

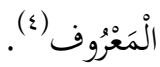

إن التوجيه النبوي الذي يأمر بطلاقة الوجه وينهى عن عبوسة الوجه، هو الإطار العام الذي ينبغي أن الن النال

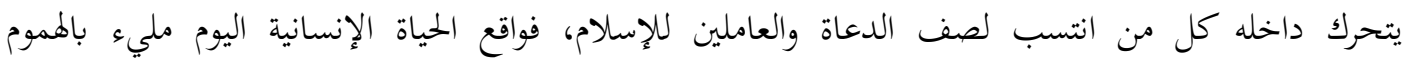

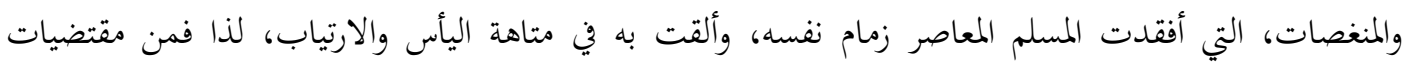

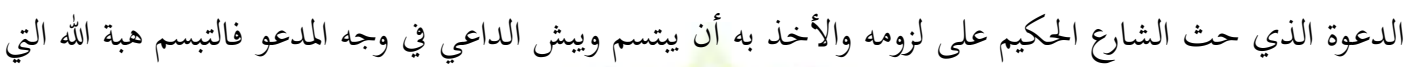

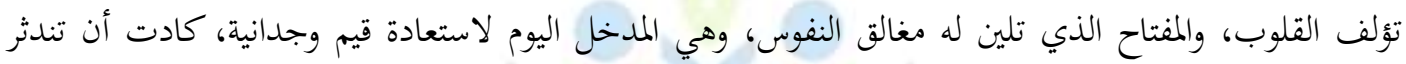
تحت وطأة اللهاث خلف المادة، والسعي للإشباع والابتلاع (ه) . لذا ينبغي على الداعية إذا رأى من قصر في أمر ربه، أن لا يُعبس عليه بوجهه، بل يُظهر البشر والبشاشة له، ويدعوه بلطف ولين، فلعله يرجع ويتوب إلى الله تعالى (ج).

(1) رواه الإمام أحمد في مسنده : مسند الشاميين، حديث عبد الله بن الحارث، رقم الحديث: (IVYIT)،

$$
\text { الشيخ شعيب: حلديث حسن. }
$$

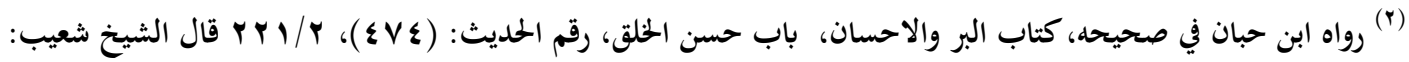

$$
\text { حديث صحيح. }
$$

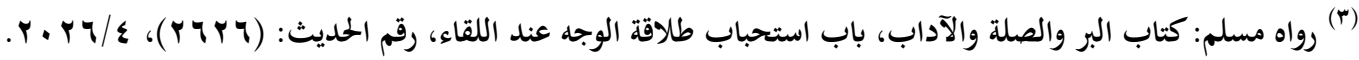

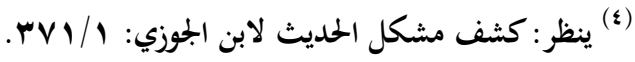

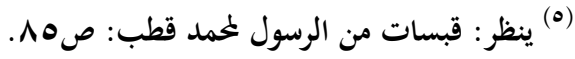

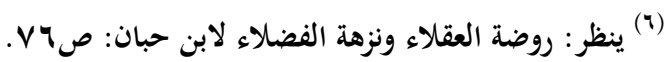

$r \leqslant r$ 
وكما أن في البسمة تأليفاً للقلوب، واستحضاراً لقيم المودة والإخاء الإنساني، فإنها كذلك زاد دعوي يهيئ

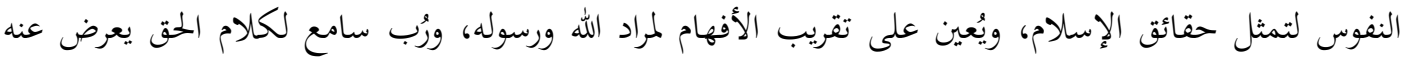

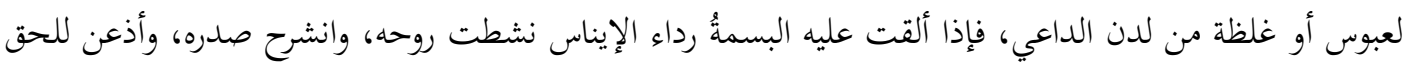

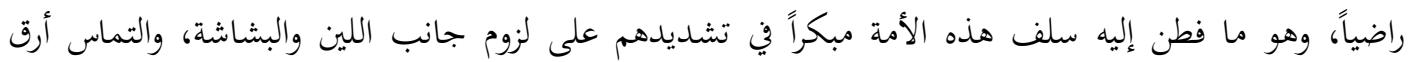
العبارات وألطف الأساليب (1). يقول الإمام ابن حبان(r): "البشاشة إدام العلماء، وسجية الحكماء؛ لأن البشر يطفئ نار المعاندة، ويحرق

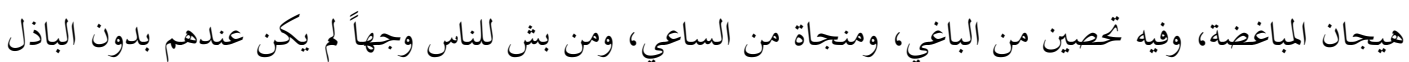

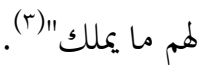
ويقول الإمام سفيان بن عيينه (ت 191)): "التبسم مصيدة المودة، والبر شيء هين: وجه طليق وكلام لين "( ) ويقول الإمام أبو حامد الغزالي(ه ـ0هـ): في سياق الرد على العالم الذي يصعر خده للناس كأنه معرض

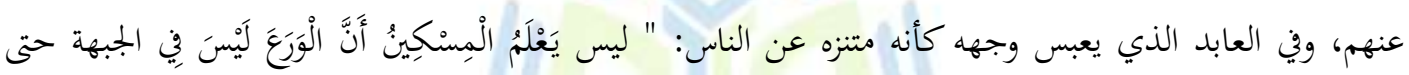

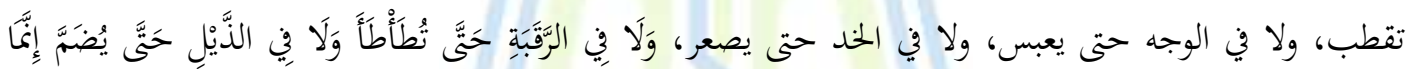

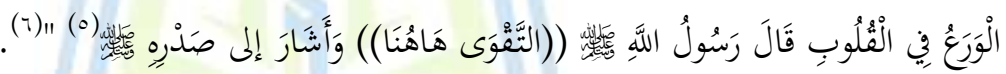

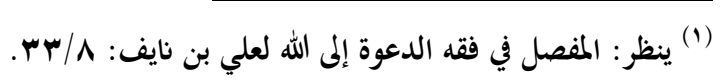

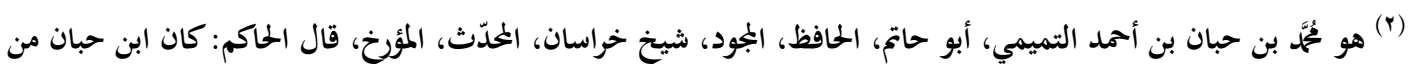
أوعية العلم في الفقه واللغة والحديث والوعظ ومن عقلاء الرجال، من مصنفاته: تاريخ الثقات، علل أوهام المؤرخين؛

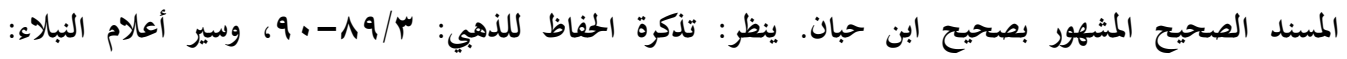

$$
\begin{aligned}
& \text {. IN } \varepsilon-1 \Lambda T / M \\
& \text { (ك) روضة العقلاء ونزهة الفضلاء: ه ه }
\end{aligned}
$$

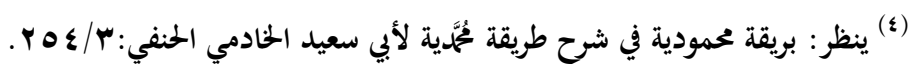

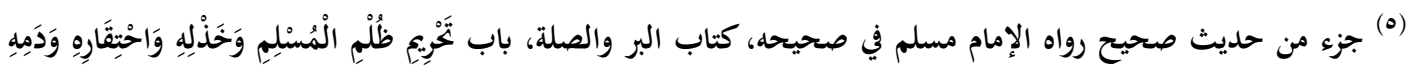

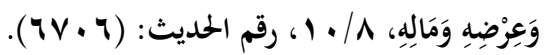

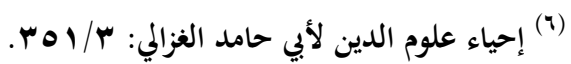

$r \leq \varepsilon$ 


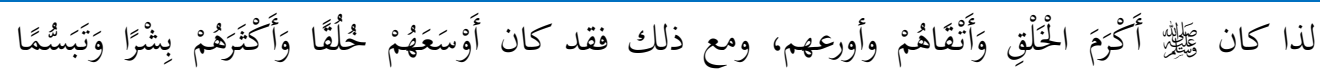
وَانْبِسَاطًا' (1)

\section{المطلب الثاني: الاحترام وأثره في الدعوة إلى اللهوئكي}

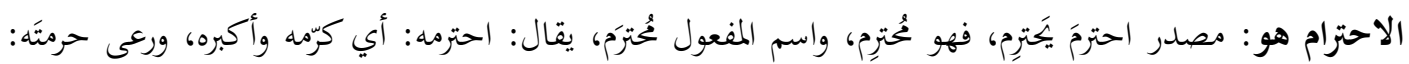

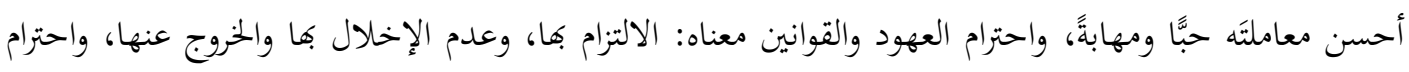

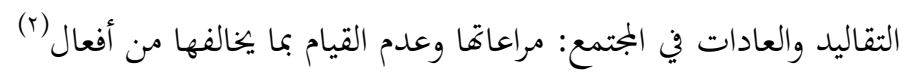

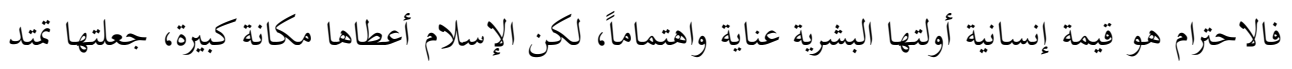

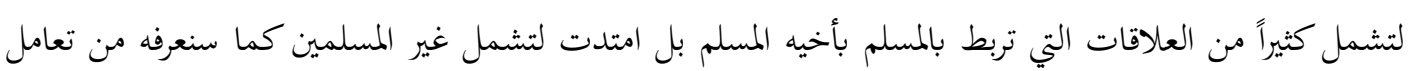

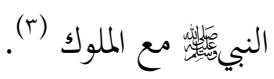

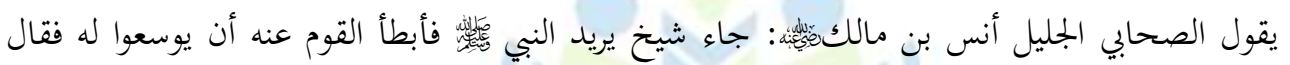

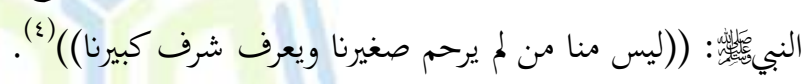
وقال

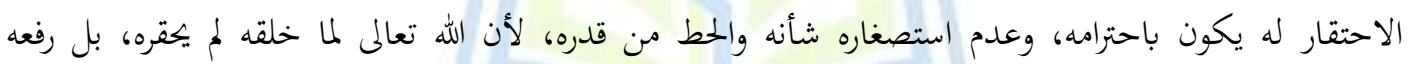

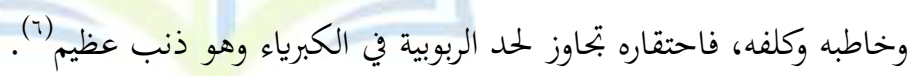

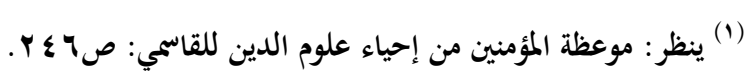

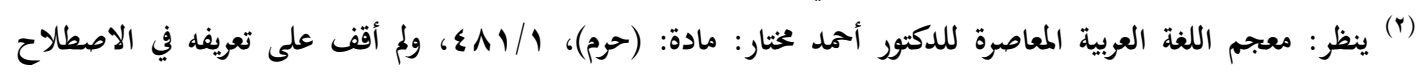
والمتعارف عليه: هو إظهار المودة والتقدير للآخرين.

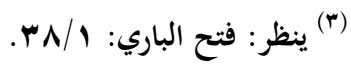

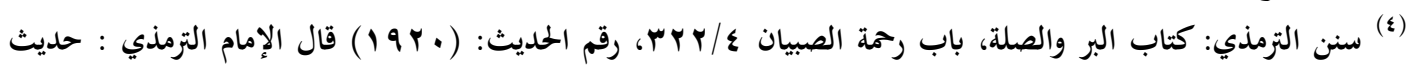
صحيح.

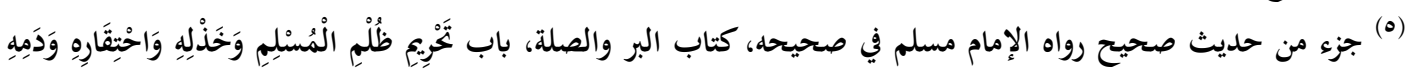

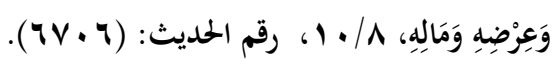

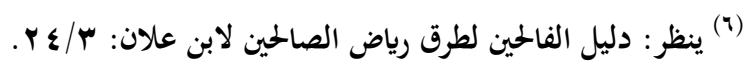
$r \leq 0$ 
واحترام الآخر لا يقتصر على المسلمين، بل يشمل غير المسلمين أيضا ما لم يكونوا حربيين، أما تخصيص

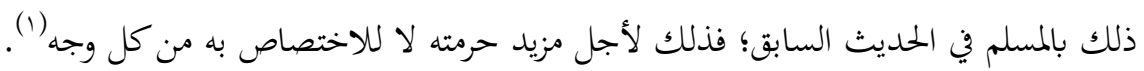

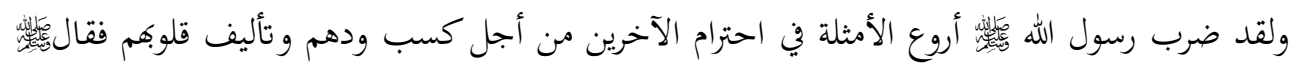

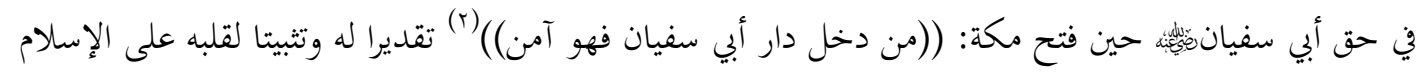

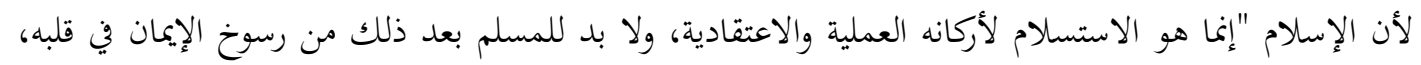

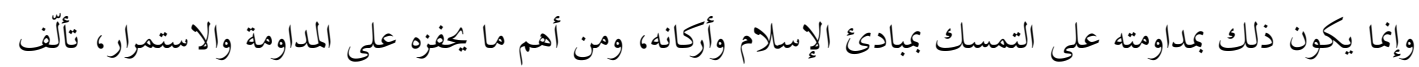

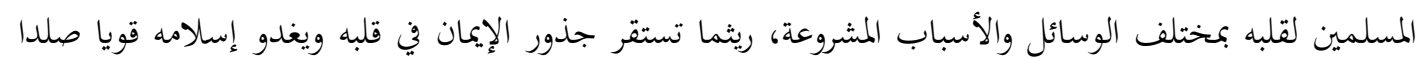

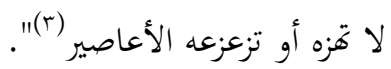
ومن أساليب احترام غير المسلمين لكسب مودقمم ودخولم في الإسلام: مناداقم بما يليق بهم من ألقاب

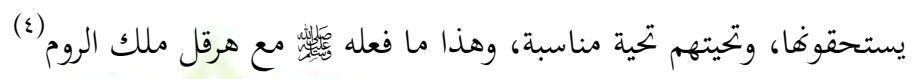

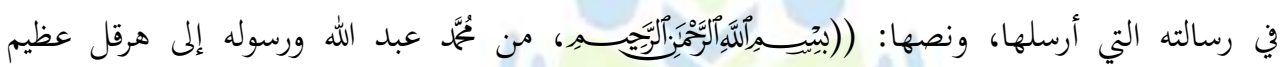
(الروم)(م)

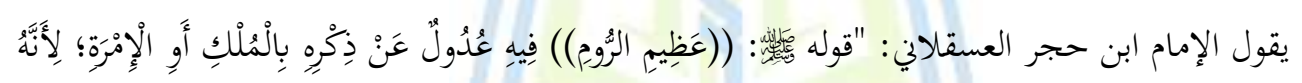

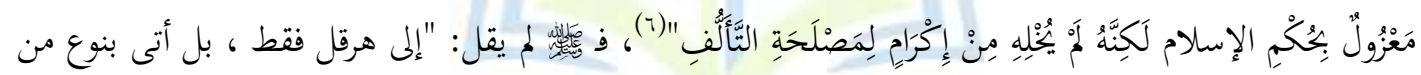

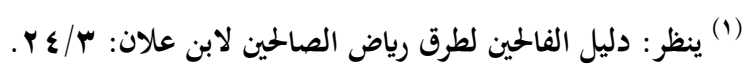

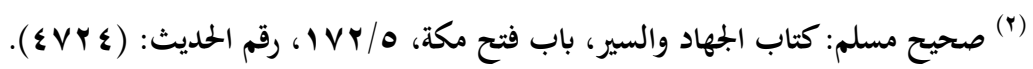

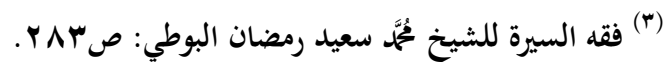

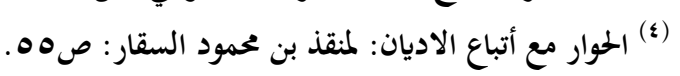

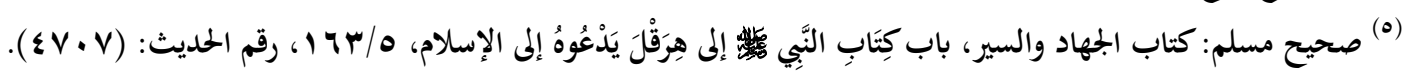
.$(\leqslant v \cdot V)$ $r \leq T$

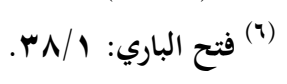


من الملاطفة فقال: ((عظيم الروم))، أي الذي يعظمونه ويقدمونه"(1)؛ ليعلمنا كيف نحترم الآخرين ولو كانوا كافرين، من أجل كسب قلوبكم و تألفها.

المطلب الثالث: الزيارة وأثرها في الدعوة إلى الله ئَيل:

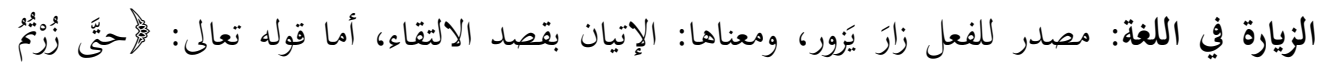

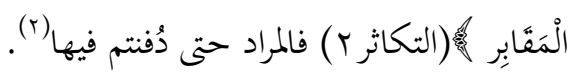

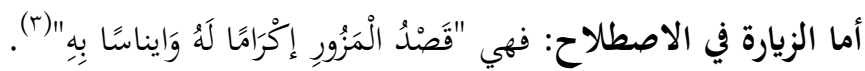

ولاشك أن لهذا القصد الاثر الكبير في نفس المزور وتأليف قلبه، خاصة إذا كانت الزيارة ججردة عن المصالح

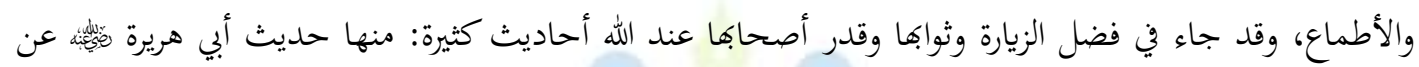

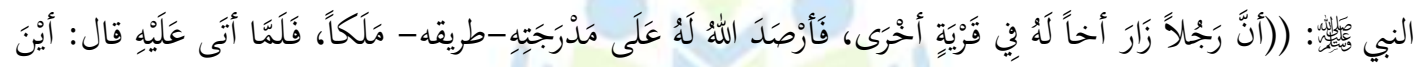

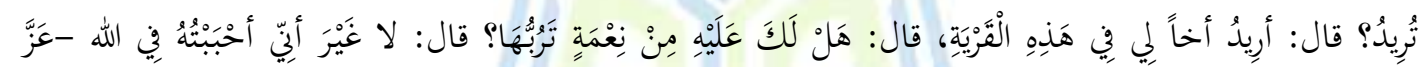

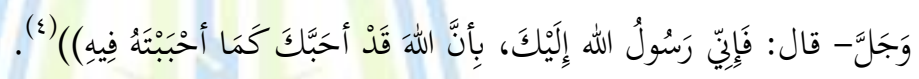

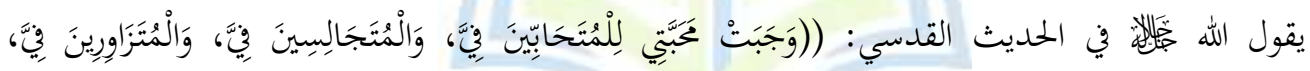

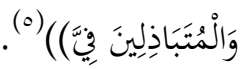

والزيارة لها مردودها الكبير في نفس المزور، ناهيك عن ما يكون فيها من إيناس، وشد الأزر، وتثبيت القلب، ولمثل هذه المقاصد طلب النبي -عليه الصلاة والسلام- من جبريل -عليه السلام- تكرار زيارته، عَنِ ابْنِ

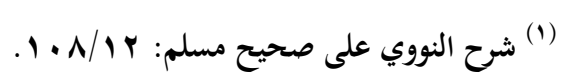

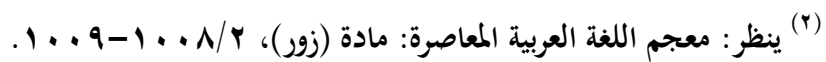

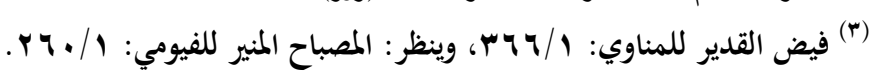

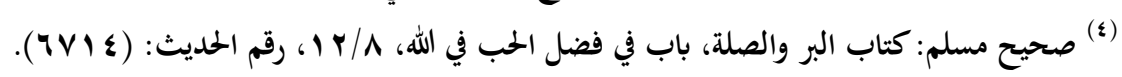

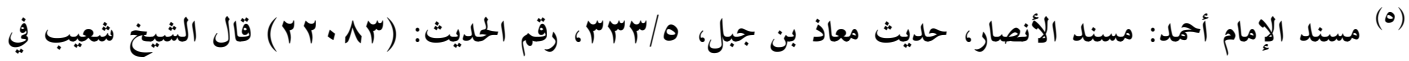
$r \leqslant Y$

$$
\text { تحقيقه على المسند: (حديث صحيح). }
$$




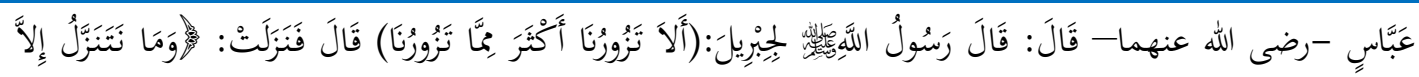

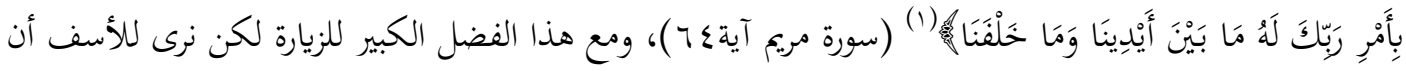

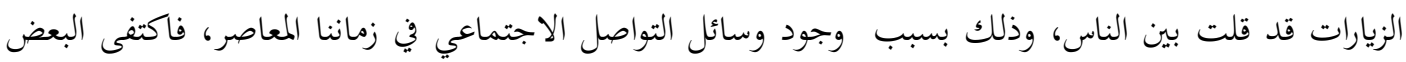

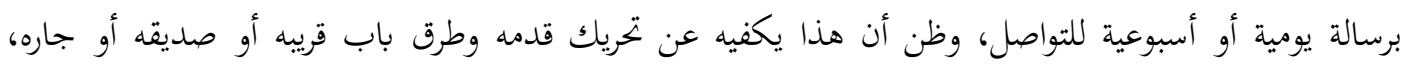

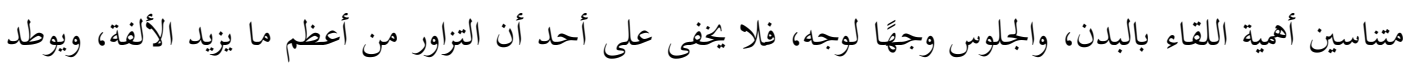

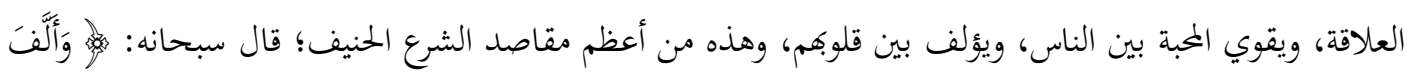

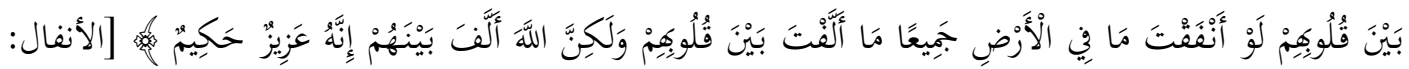

يقول الإمام ابن حبان: "الواجب على العاقل تعاهد الزيارة للإخوان وتفقد أحوالهم؛ لأن الزائر في قصده

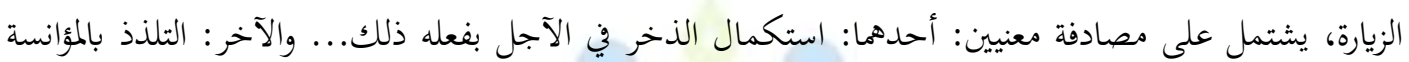

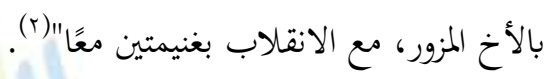
فالزيارة لها سحر تصنعه في قلوب كثير من الناس، خاصة العصاة والمذنبين، ولقد كان المعلم الأول

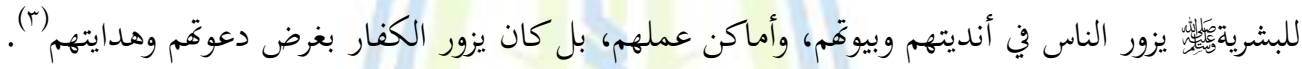

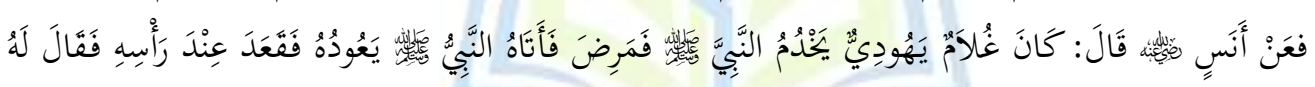

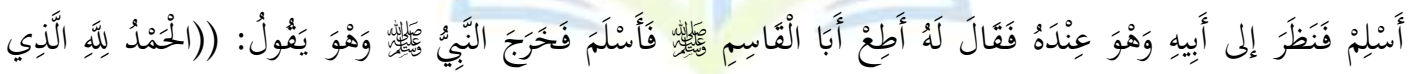

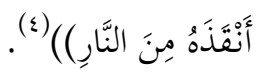
ففي الحديث: دليل على جواز زيارة أهل الذمة، خاصة إذا كان جارا له، لأن فيها إظهار محاسن الإسلام، وزيادة التأليف بمم ليرغبوا في الإسلام (0).

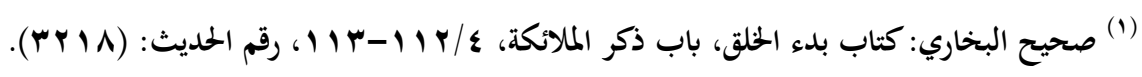

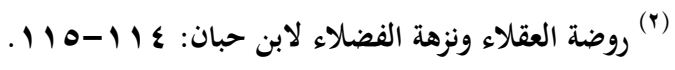

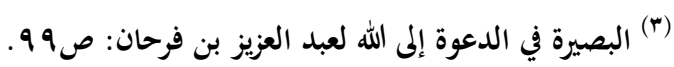

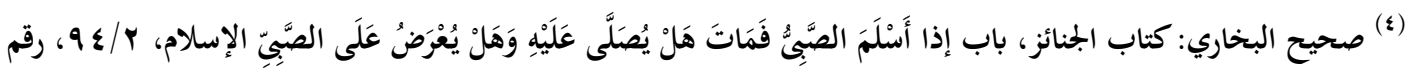

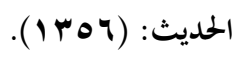

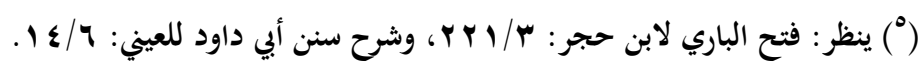
$r \leqslant \wedge$ 


\section{المبحث الثاني: التودد بالوسائل المادية

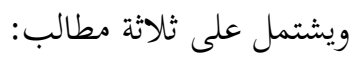

المطلب الأول: المدية وأثرها في الدعوة إلى الله تعلى:

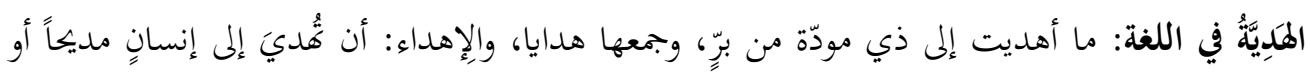

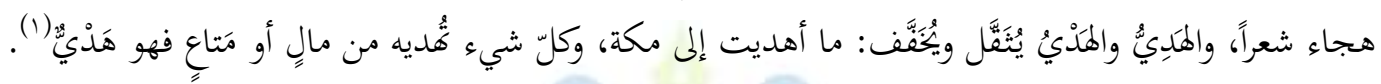

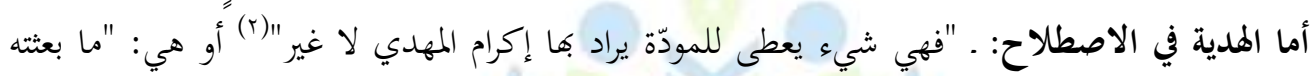

$$
\text { لغيرك إكراما"(r) }
$$

ودينا الحنيف يدعو إلى كل وسيلة تدعو إلى المبة والألفة والأخوة، ومن هذه الوسائل التي تتحقق بما هذه

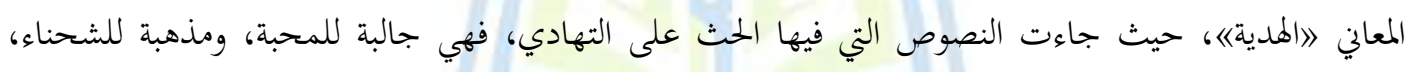

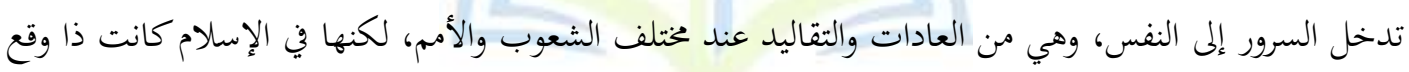

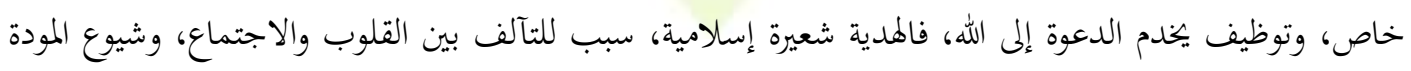

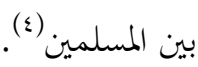

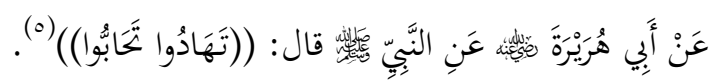

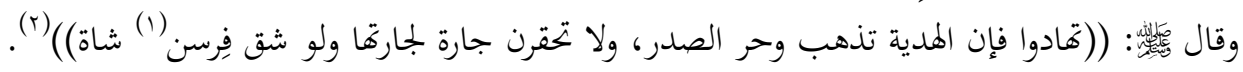

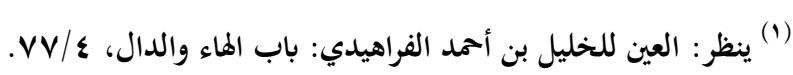

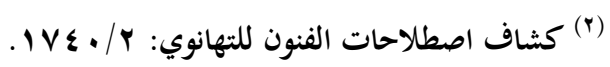

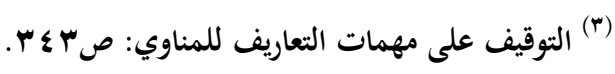

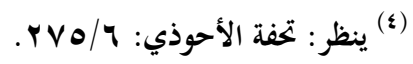

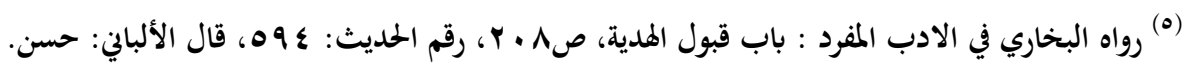

$r \leq q$ 


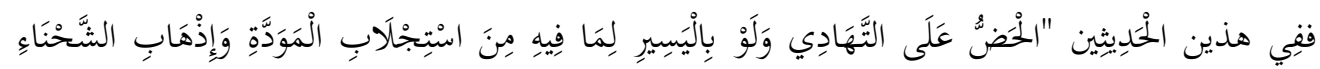

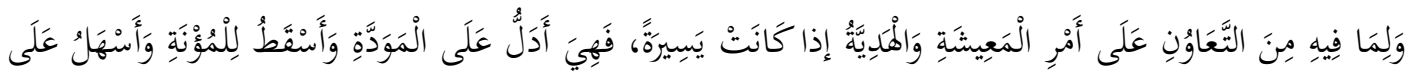

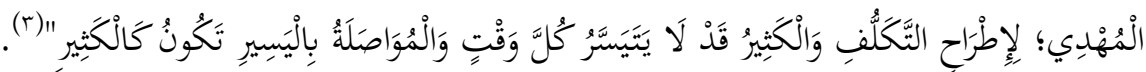

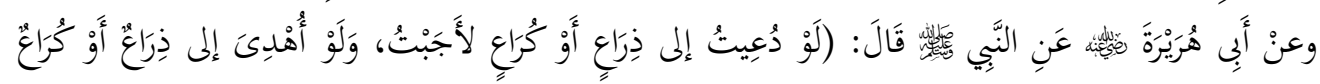

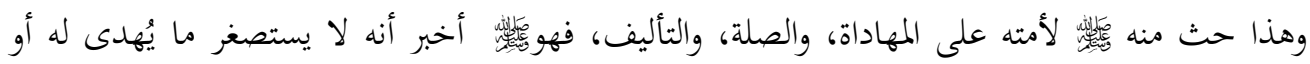

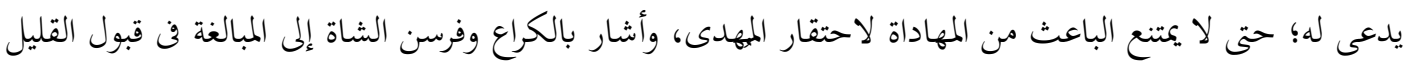

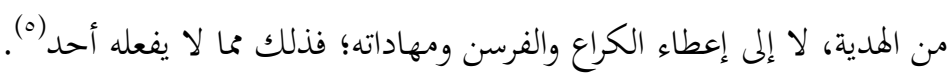

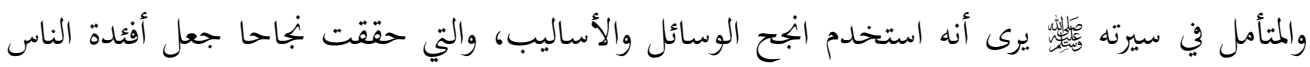

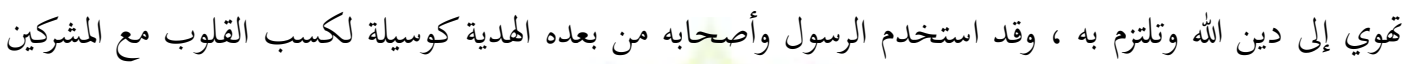

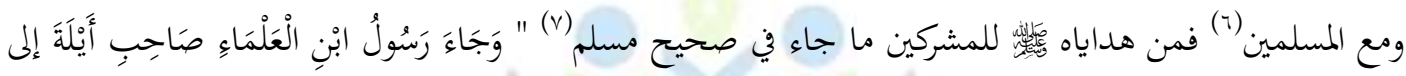

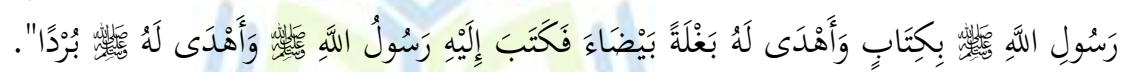

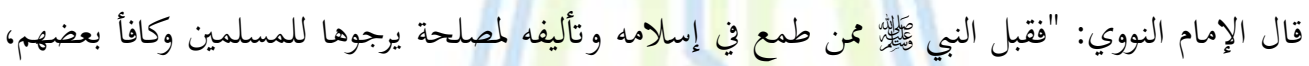

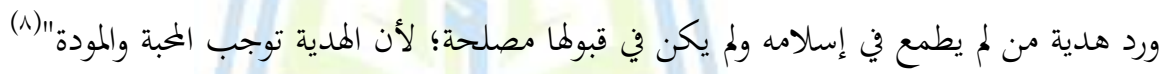

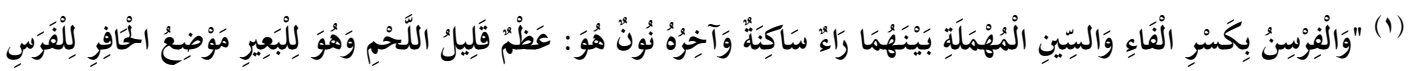

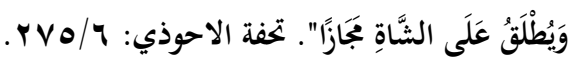

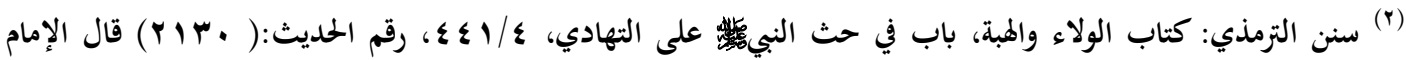

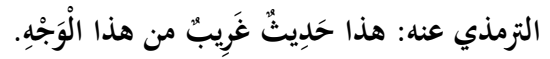

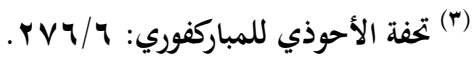

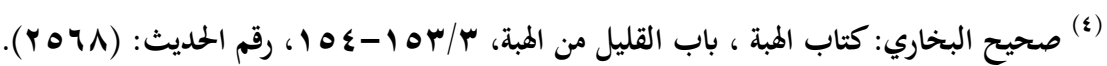

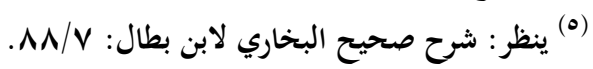

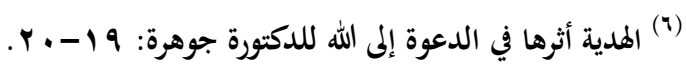

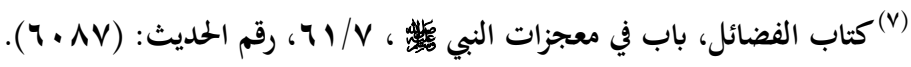

ro.

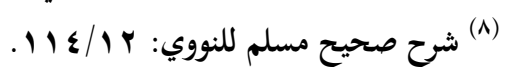




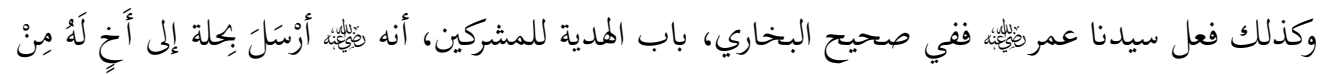

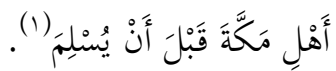

أما هداياه

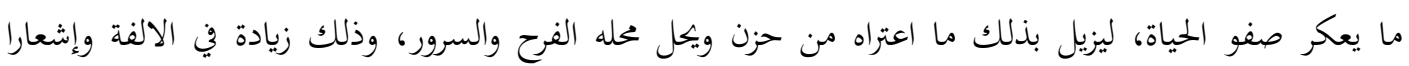

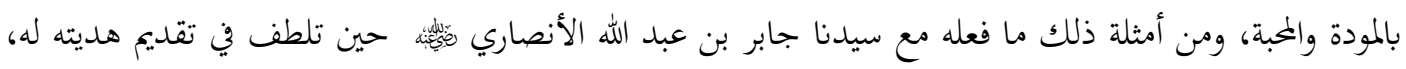

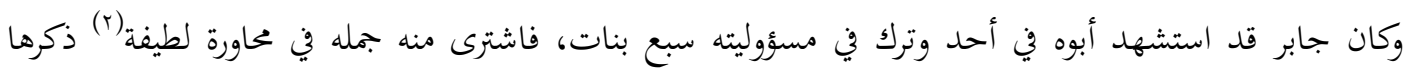

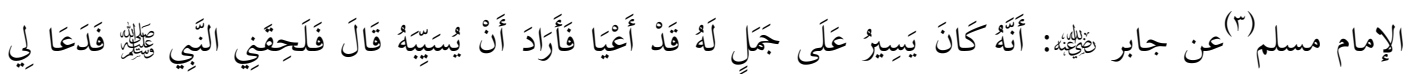

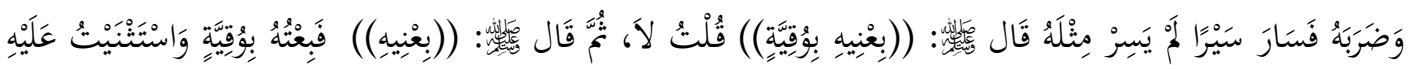

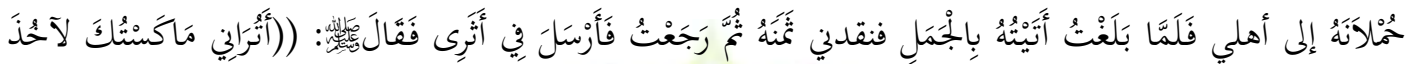

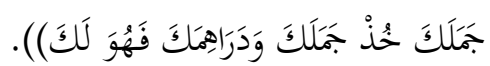

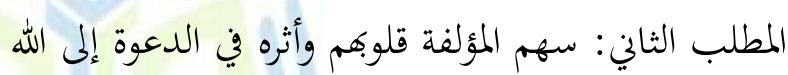

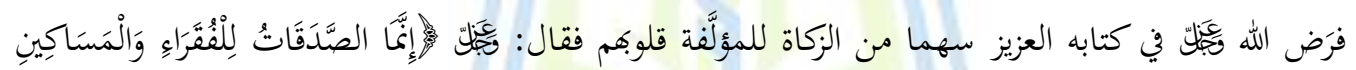

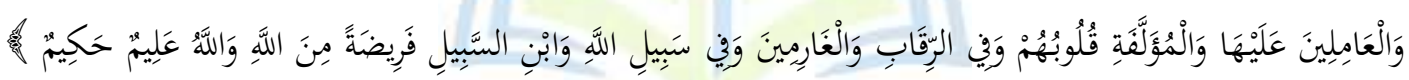

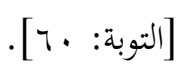

والمؤلفة في اللغة: جمع مؤلف من التَأْلِيف وَهُوَ جمع الْقُلُوب، يقال: تألفََ القوم: بمعنى اجتمعوا وتحابوا،

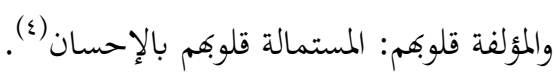

(1)

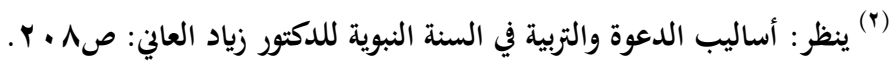

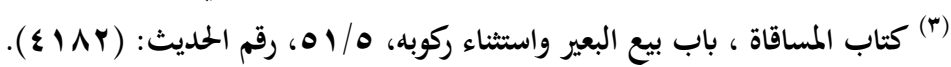

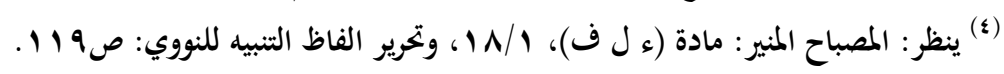

rol 
أما في الاصطلاح: فقد اختلف فيه" فقيل: هم صنف من الكفار يعطون ليتألفوا على الإسلام، وكانوا لا يسلمون بالقهر والسيف، ولكن يسلمون بالعطاء والإحسان.

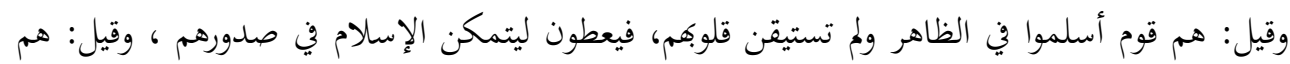

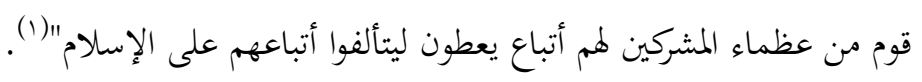

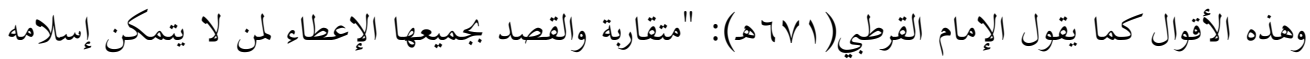

$$
\text { حقيقة إلا بالعطاء، فكأنه ضرب من الجهاد"(r). }
$$

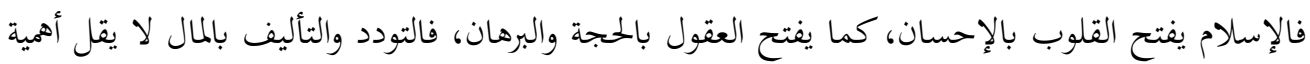

$$
\text { من أسلوب الاقناع بالحجة والبرهان (r). }
$$

فالمدعوون- سواء كانوا كفارا أو مسلمين ضعفاء النية- صنفين: فصنف يرجعاد ويتأثر بالدليل والبرهان

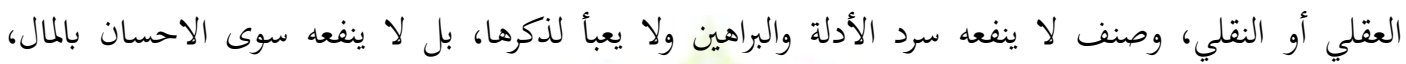

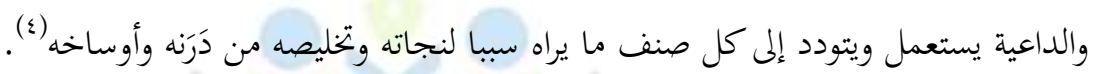

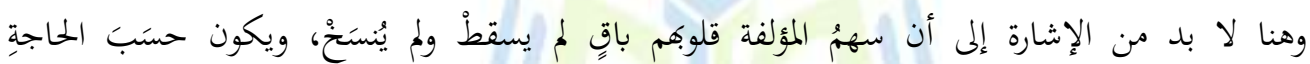

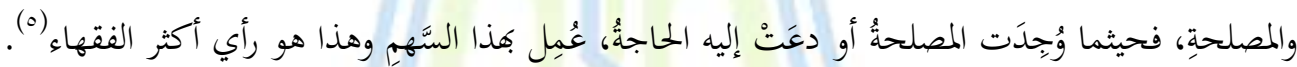
فالعطاء والاحسان بالمال يرقق القلوب، ويزيل ضغائن القلوب، ويطفئ نار الحقد المشتعلة في القلوب،

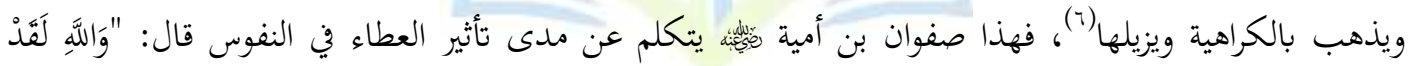
أعطاني رَسُولُ المَّهُ

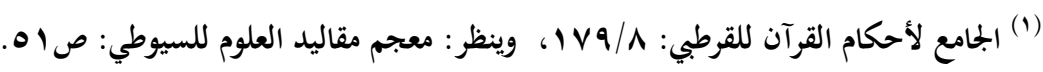

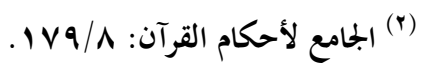

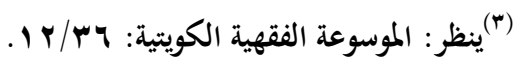

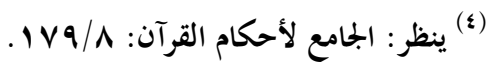

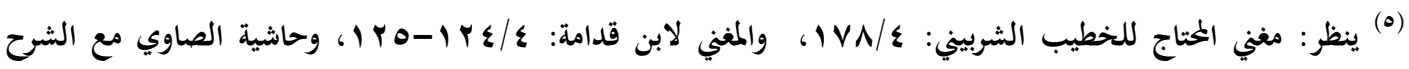

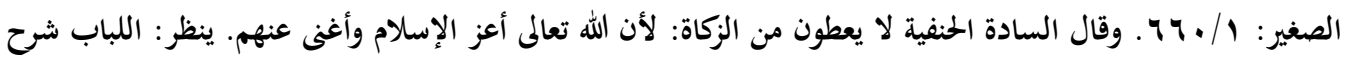

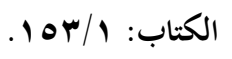

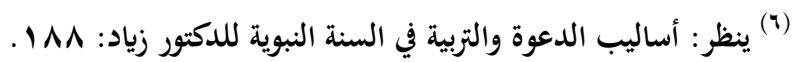

ror 


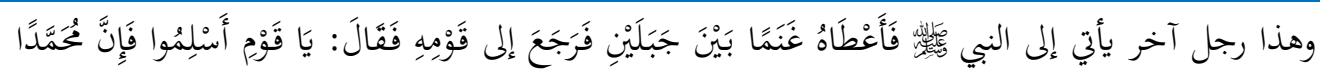

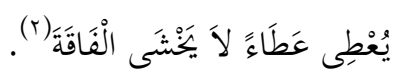

وهذا العطاء سواء للكافر أو لضعيف الايمان إنما هو لترغيبه وتأليفه لحين اسلامه او زيادة إيمانه؛ فإذا دخل

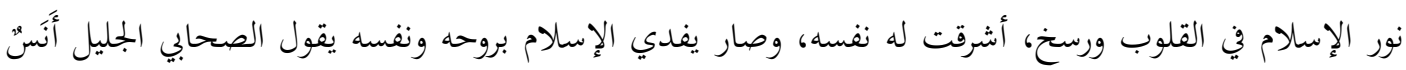

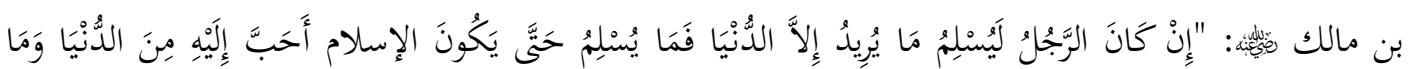

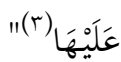

\section{المطلب الثالث: اقامة الولائم وأثرها في الدعوة إلى الله كئلئ}

الولائم جمع وليمة وهي لغة وعرفا: "اسم لكل طعام يتخذ لجمع"(؛)، وقيل: "هي طعام العُرس(ن)".

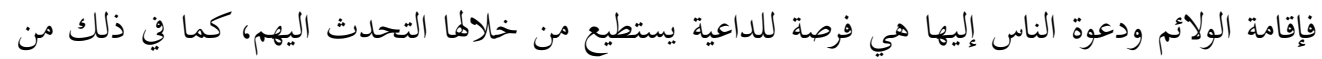

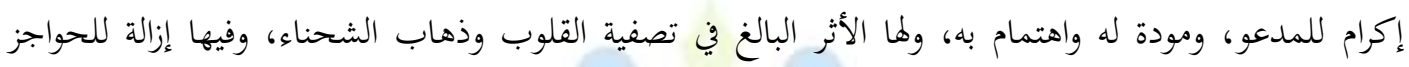

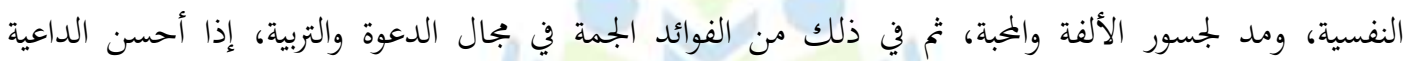
استغلال ذلك، وروعي فيها المساواة بين المدعوين على اختلاف مستوياقم الفكرية والثقافية والاجتماعية(ا). وقد استخدم النبي

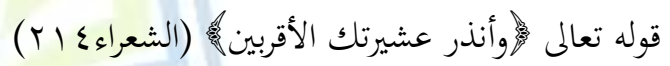

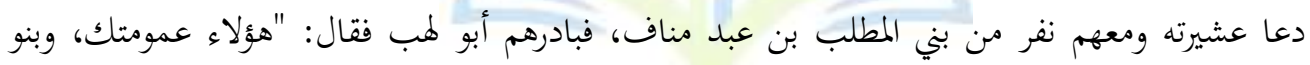

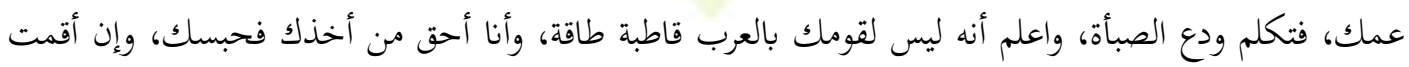

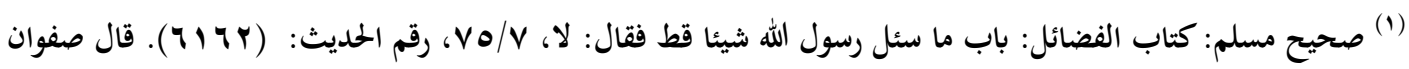
ذلك: عندما أعطاهِ

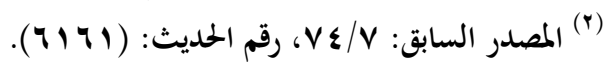

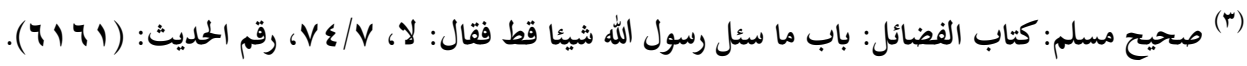

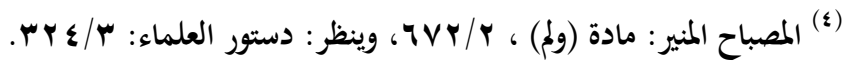

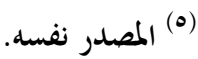

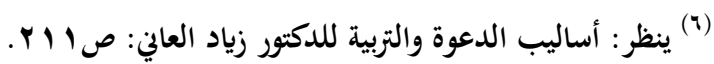

ror 
على ما أنت عليه فهو أيسر عليهم من أن يثب بك بطون قريش وتمدهم العرب، فما رأيت أحدا جاء على بني أبيه

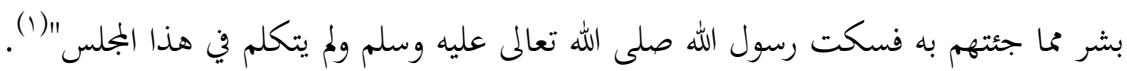

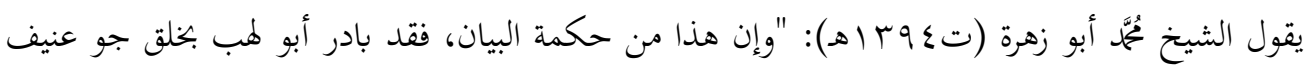

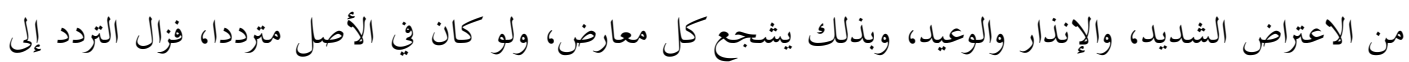

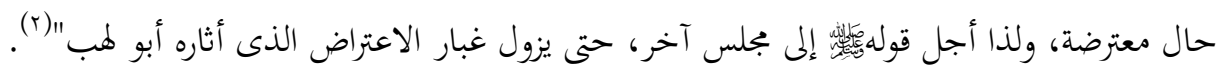

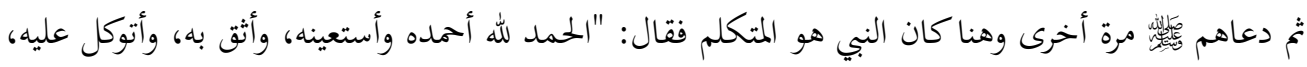

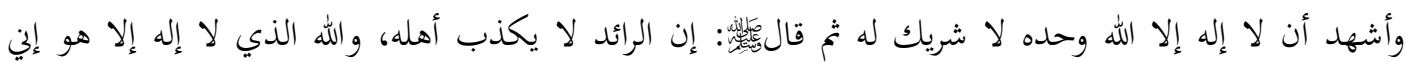

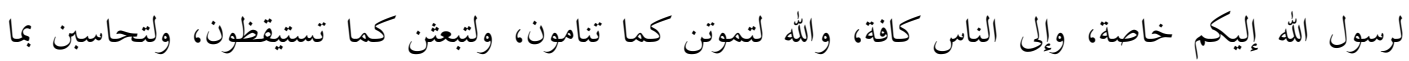

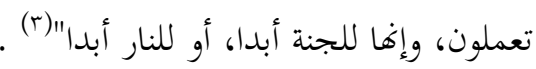

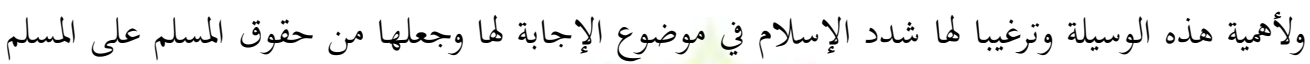

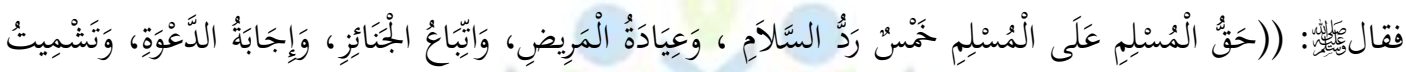
(ألعَاطِسِ)(

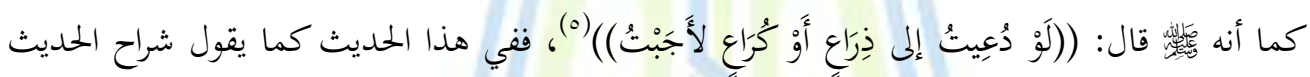

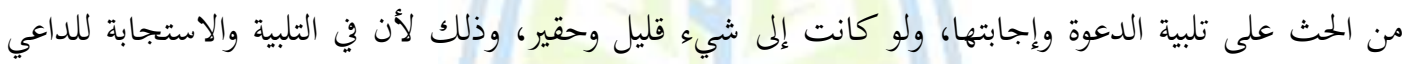

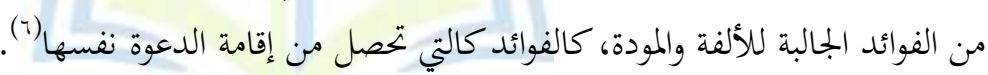

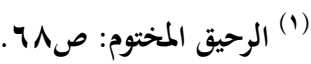

$$
\begin{aligned}
& \text { (r) }
\end{aligned}
$$

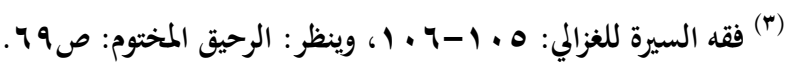

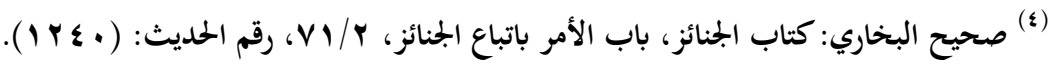

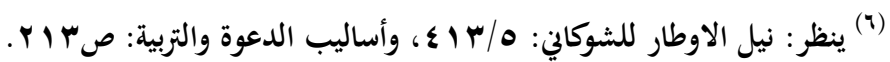

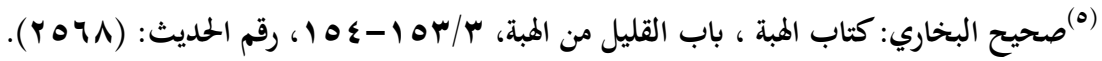

ros 


\section{الخاتمة}

بعد أنّ مَنَّ الله عليَّ بإتمام هذا البحث، أكتب هنا أهم ما توصلت اليه وهو أن:

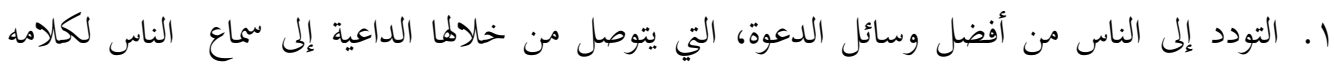
وقبوله.

r. التبسم وطلاقة الوجه لها تأثير في بعض النفوس البشرية، وتفعل ما لا تستطيع الكلمات والخطب والمواعظ من فعله.

r. الإسلام جاء رحمة للبشرية جمعاء، فكما شرع للمسلم زيارة أخيه المسلم، شرع له كذلك زيارة أخيه في الانسانية من النصارى واليهود واعطاء الهدايا لمم تأليفا لقلوبمم ورغبة في إسلامهم.

ع. العطاء المادي له تأثير في النفوس وتأليف القلوب، كتأثير العطاء المعنوي من التبسم والاحترام، لذا شرع الإسلام سهم المؤلفة قلوبم، وحث على المهاداة، وإقامة الدعوات، من أجل إزالة العقبات والحواجز بين الداعية والناس. ه. احترام الناس وتنزيل الناس منازهم مما حث عليه الإسلام، وشدد النكير على خلافه، وذلك كله لما في الاحترام من الفوائد الحسان في التأثير في الناس، فهم جبلوا على سماع كلام من يحترمهم ولا يحقرهم حتى ولو كانوا عصاة خرجوا عن طريق الصواب. 


\section{المصادر والمراجع ت المان}

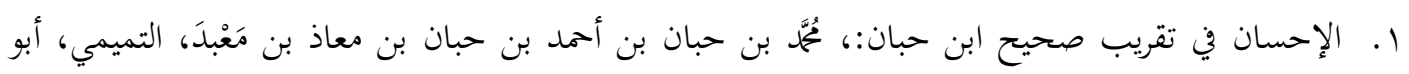
حاتم، الدارمي، البُستي (المتوف: ع عهـ)، ترتيب: الأمير علاء الدين علي بن بلبان الفارسي (المتوف: VF9 هـ)، حققه وخرج أحاديثه وعلق عليه: شعيب الأرئوط، الناشر: مؤسسة الرسالة، بيروت، طا، م.ــ إهـ .$<1911$

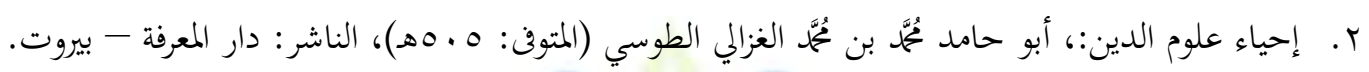

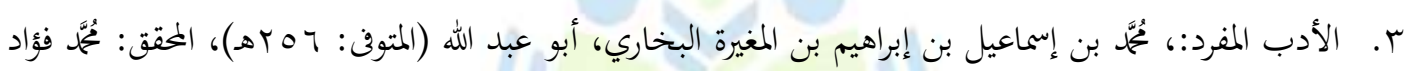
عبد الباقي، الناشر: دار البشائر الإسلامية - بيروت، طץ، 9 .ـ 1 - 1919. ع. أساليب الدعوة والتزبية في السنة النبوية: للدكتور زياد مممود العاني، دار السلام، دمشق، طا، دبعاهـ$.6 r+. \mathrm{p}$

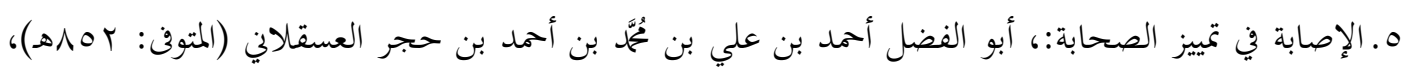
تحقيق: عادل أمد عبد الموجود وعلى يُّة معوض، الناشر: دار الكتب العلمية - بيروت، طا - 0 إعا هـ.

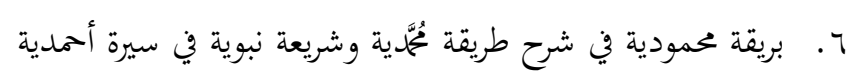
V. البصيرة في الدعوة إلى الله:، عزيز بن فرحان العزي، قديم: صالح بن عبد العزيز آل الشيخ، الناشر: دار الإمام

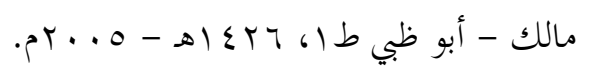

roT 
1. بلغة السالك لأقرب المسالك المعروف بحاشية الصاوي على الشرح الصغير (الشرح الصغير هو شرح الشيخ الدردير لكتابه المسمى أقرب المسالك لِمَذْهَبِ الإمام مَالكِكٍ)، أبو العباس أحمد بن عُمَّمَ الحلوتي، الشهير بالصاوي المالكي (المتوف: إع اهـ)، الناشر: دار المعارف الطبعة: بدون طبعة وبدون تاريخ.

9.تحرير ألفاظ التنبيه:، أبو زكريا محيي الدين يهيى بن شرف النووي (المتوف: جلحهـ)، المحقق: عبد الغني الدقر، الناشر: دار القلم - دمشق، ط ا، م.•ـا.

• 1.تحفة الأحوذي بشرح جامع الترمذي:، أبو العلا تمُحَّ عبد الرحمن بن عبد الرحيم المباركفوري، (المتوف: ror (r اهـ)، الناشر: دار الكتب العلمية - بيروت.

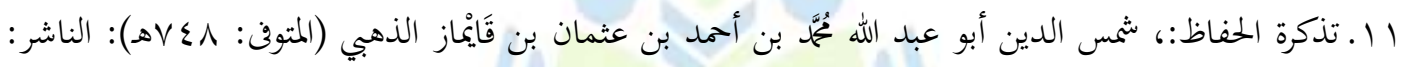
دار الكتب العلمية بيروت-لبنان، ط1، 9 إ1 اهـ- 991 م.

ז ا. التعريفات:، علي بن ثُمَّمَ بن علي الجرجاني، سنة الوفاة: (7 اهه)، تحقيق: إبراهيم الأبياري، الناشر: دار الكتاب العربي، سنة النشر: 0.ـ اهـ، مكان النشر: بيروت.

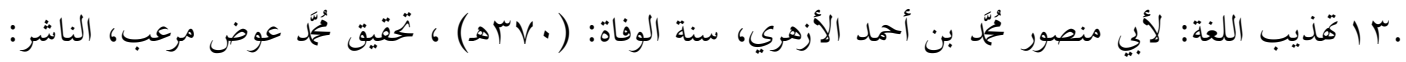
دار إحياء التراث العربي ، سنة النشر: ل . . بم، مكان النشر: بيروت .

ع ا. التوقيف على مهمات التعاريف:، زين الدين مُحمَّم المدعو بعبد الرؤوف بن تاج العارفين بن علي بن زين العابدين الحدادي ثم المناوي القاهري (المتوف: اس. اهـ)، الناشر: عالم الكتب، القاهرة، طا، ــإهـ- 
1. الجامع الصحيح المسمى صحيح مسلم:، أبو الحسين مسلم بن الحجاج بن مسلم القشيري النيسابوري، الناشر: دار الجيل بيروت + دار الأفاق الجديدة ـ بيروت.

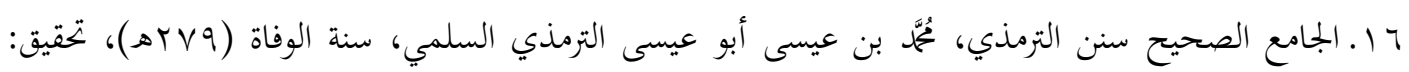
أحمد مُحمّمَ شاكر وآخرون، الناشر: دار إحياء التراث العربي.

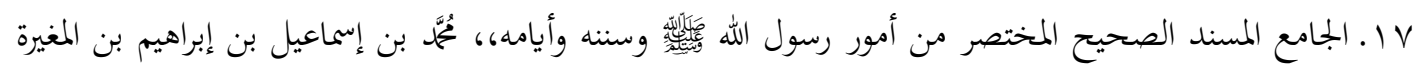

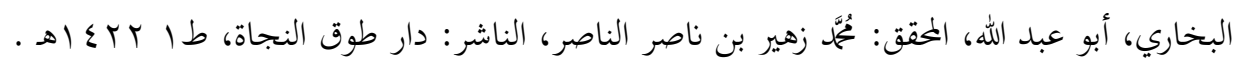

1 1. الجامع لأحكام القرآن، أبو عبد الله ثُحَّمَ بن أحمد بن أبي بكر بن فرح الأنصاري الخزرجي شمس الدين القرطبي (المتوفى: الم هـ) المحق: هشام سمير البخاري، الناشر: دار عالم الكتب، الرياض، المملكة العربية السعودية،

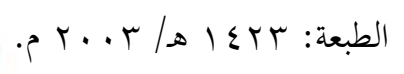

19 . حوار مع أتباع الأديان مشروعيته وآداها، منقذ بن محمود السقار، الناشر: رابطة العالم الإسلامي.

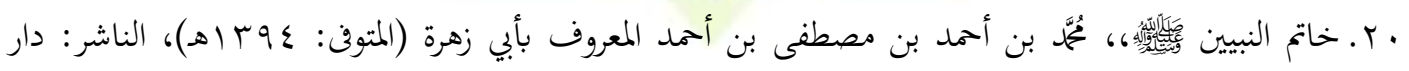

$$
\text { الفكر العربي - القاهرة، عام النشر: 0بع ا هـ. }
$$

اب. دستور العلماء أو جامع العلوم في اصطلاحات الفنون، القاضي عبد النبي بن عبد الرسول الأمد نكري، تحقيق عرب عباراته الفارسية: حسن هاني فحص، الناشر دار الكتب العلمية، سنة النشر ابع اهـ-.... بم، مكان النشر لبنان / بيروت. 


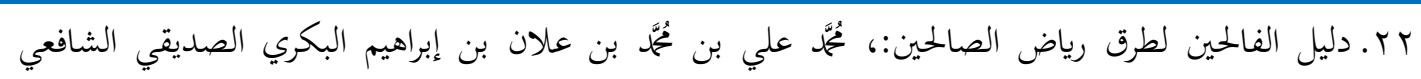

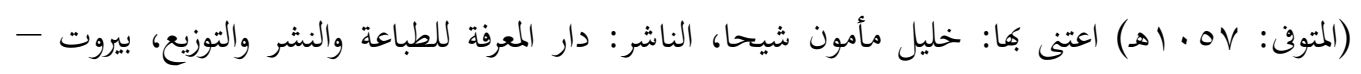

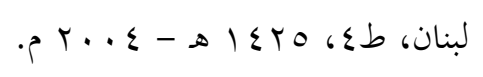

بr. الرحيق المختوم، صفي الرمن المباركفوري (المتوفن: VY乏 اهـ)، الناشر: دار الهلال، طا.

ع r. روضة العقلاء ونزهة الفضلاء:، عُمَّمَ بن حبان بن أحمد بن حبان بن معاذ بن مَعْبَ، التميمي، أبو حاتم،

الدارمي، البُستي (المتوفن: ع هـه)، المحقق: ثُحَّمَ محي الدين عبد الحميد، الناشر: دار الكتب العلمية - بيروت.

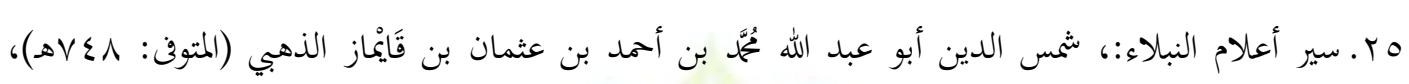

$$
\text { الناشر: دار الحديث- القاهرة، الطبعة: VYع اهـ-7 . Trم. }
$$

דr. شرح النووي على صحيح مسلم:، أبو زكريا يهيى بن شرف بن مري النووي، سنة الوفاة: (דVIهـ) الناشر دار

$$
\text { إحياء التراث العربي، سنة النشر: بو ب اهـ ، مكان النشر: بيروت. }
$$

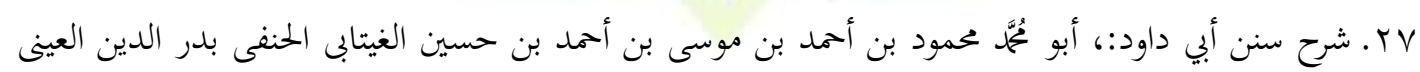

(المتوفى: 100هـ)، المحقق: أبو المنذر خالد بن إبراهيم المصري، الناشر: مكتبة الرشد - الرياض، طا، . بع إ

$$
\text { . } 1999-8
$$

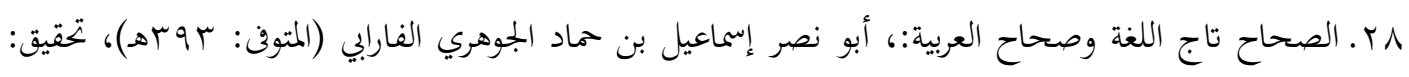

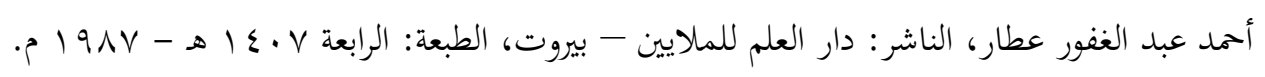


وr. العين:، الخنيل بن أحمد الفراهيدي، سنة الوفاة: (V0 اهـ)، تحقيق: د. مهدي المخزومي / د إبراهيم السامرائي، الناشر: دار ومكتبة الهلال.

•r. فتح الباري شرح صحيح البخاري،، أحمد بن علي بن حجر أبو الفضل العسقلاني الشافعي سنة الوفاة:

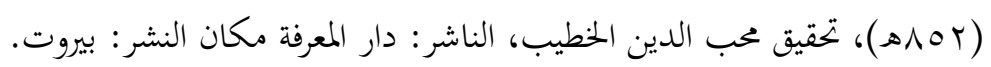

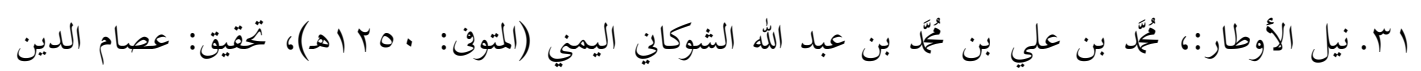

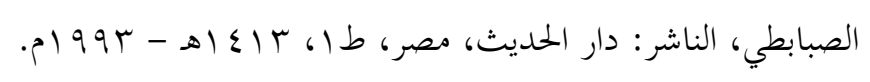

rr. فقه السيرة النبوية مع موجز لتاريخ الخلافة الراشدة،، محّمد سَعيد رَمضان البوطي الناشر: دار الفكر - دمشق، D.

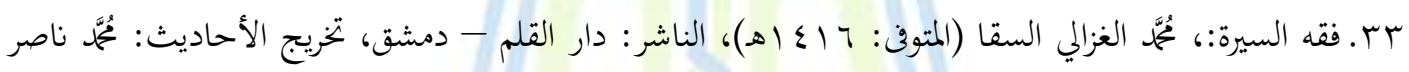

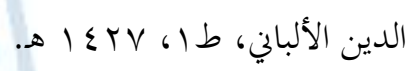

عَr. فيض القدير شرح الجامع الصغير،، زين الدين يُمَّمَ المدعو بعبد الرؤوف بن تاج العارفين بن علي بن زين العابدين الحدادي ثم المناوي القاهري (المتوفن: اب. (هـ)، الناشر: المكتبة التجارية الكبرى - مصر، طا، . 1 Thot

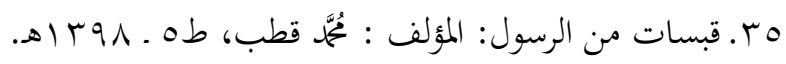
بس. كشف المشكل من حديث الصحيحين:، جمال الدين أبو الفرج عبد الرمن بن علي بن عُمَّمَ الجوزي (المتوف:

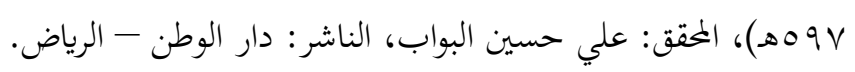

r.. 
VV. اللباب في شرح الكتاب، عبد الغني بن طالب بن حمادة بن إبراهيم الغنيمي الدمشقي الميداني الحنفي (المتوف: مج r (اه)، حققه، وفصله، وضبطه، وعلق حواشيه: تُحَّة محيي الدين عبد الحميد، الناشر: المكتبة العلمية، بيروت - لبنان.

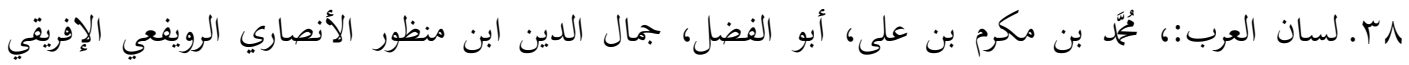

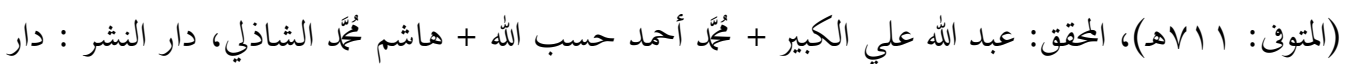
المعارف، القاهرة.

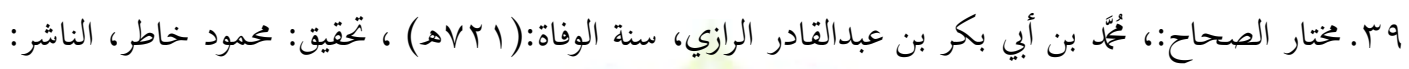
مكتبة لبنان ناشرون، سنة النشر: 10 1990 190، مكان النشر: بيروت.

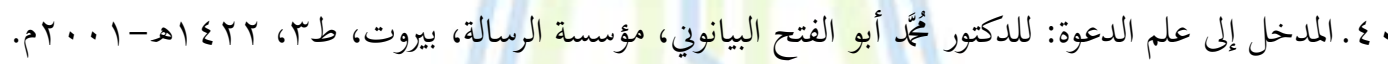
اء ـ. مسند الإمام أحمد بن حنبل: المؤلف : أحمد بن حنبل أبو عبدالله الشيباني، الناشر : مؤسسة قرطبة - القاهرة ، الأحاديث مذيلة بأحكام شعيب الأرنؤوط عليها.

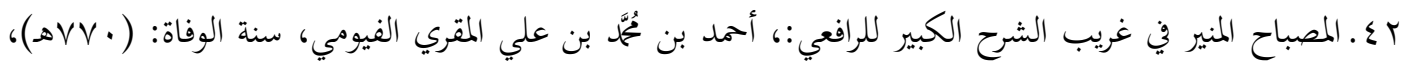
الناشر المكتبة العلمية بدون طبعة ولا تاريخ.

بع ـ الهدية وأثرها في الدعوة إلى الله: اعداد الدكتورة الجوهرة بنت صالح بن حمود الطريفي، بحث مقدم إلى جامعة الإمام مُحَّمَ بن سعود الإسلامية بدون طبعة ولا تاريخ. 


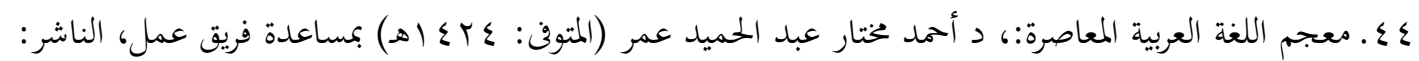

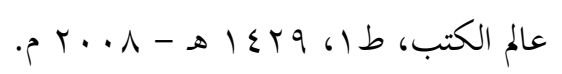

هـ معجم مقاليد العلوم: أبو الفضل عبد الرحمن جلال الدين السيوطي، سنة الوفاة: (119هـ)، تحقيق أ.د مُحَّم إبراهيم عبادة، الناشر مكتبة الآداب، سنة النشر ع ؟ع اهـ - ع . . بم ، مكان النشر: القاهرة / مصر. كـ ـ المغرب في ترتيب المعرب:، ناصر بن عبد السيد أبى المكارم ابن على، أبو الفتح، برهان الدين الحوارزمي

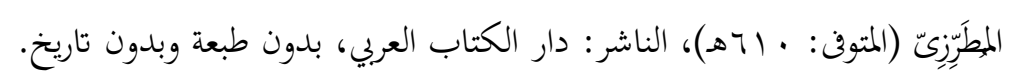

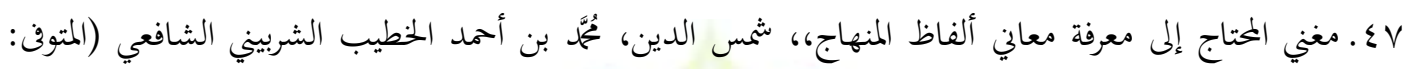

$$
\text { (هVY }
$$

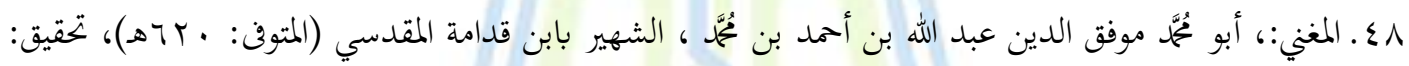
الدكتور عبد الله بن عبد المحسن التركي، والدكتور عبد الفتاح تُمَّمَ الحلو، ط: عالم الكتب، الرياض -

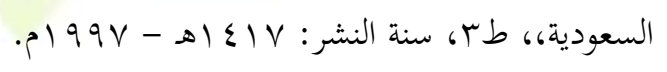

9 ــ الموسوعة الفقهية الكويتية: صادرة عن: وزارة الأوقاف والشئون الإسلامية - الكويت، عدد الأجزاء: 0ـ جزءا

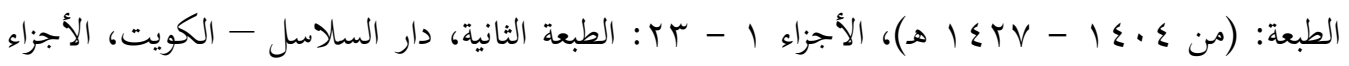

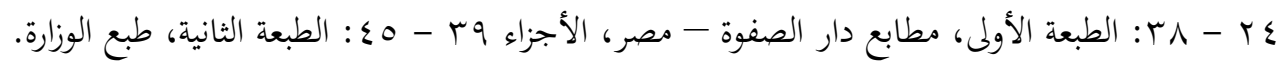
•ـ. النهاية في غريب الحديث والأثر لابن الأثير: لأبي السعادات المبارك مُحَّم الجزري، تحقيق: طاهر أحمد الزاوي ومحمود مُحَّمَ الطناجي، المكتبة العلمية، بيروت. 